Revista lus et Praxis, Año 22, No 1, 2016, pp. 87 - 128

ISSN 0717 - 2877

Universidad de Talca - Facultad de Ciencias Jurídicas y Sociales

El perjuicio como justificación de la revocación concursal Juan Luis Goldenberg Serrano

Trabajo recibido el 19 de junio y aprobado el 16 de septiembre de 2015

\title{
El perjuicio como justificación de la revocación concursal ${ }^{*}$
}

THE DETRIMENT AS JUSTIFICATION OF CLAW-BACK ACTIONS

Juan Luis Goldenberg SerRano**

\section{RESUMEN}

El presente trabajo pretende efectuar un acercamiento a la noción de perjuicio que envuelve el ejercicio de las acciones revocatorias concursales previstas en el Capítulo VI de la Ley No 20.720. Al efecto, se propone que el 'perjuicio' no se presenta como un concepto unívoco en las diversas acciones reguladas en nuestro ordenamiento, sino que se disocia en el perjuicio a la masa pasiva y a la masa activa. De este modo, la comprobación del requisito se deberá efectuar en consideración a sus propios términos específicos, lo que, a su vez, tiene incidencia en los efectos jurídicos aplicables al caso y en la ponderación de la correcta asignación del riesgo de revocación de los actos para no alterar las bases fundamentales de la certeza jurídica.

\section{ABSTRACT}

This article aims to approach the notion of detriment that is considered for the purposes of the exercise of the claw-back actions regulated in Chapter VI of Act $N^{0} 20,720$. In this sense, we propose that the term 'detriment' is not a univocal concept for the different actions considered in our legal system, but that it is dissociated in the detriment to the creditors and to the estate. As such, the accreditation of such requisite shall be conducted in accordance to its own special terms, which, in turn, impacts the legal effects applicable to the case and the consideration of an adequate allocation of the risk of revocation of the acts in order not to alter the main basis of the legal certainty.

Palabras Clave

Derecho concursal, Acciones revocatorias, Perjuicio

KEYWORDS

Insolvency law, Claw-back actions, Detriment

\section{Introducción}

Una de las tantas novedades que se contienen en la Ley $N^{\circ} 20.720$, de 9 de octubre de 2014, de reorganización y liquidación de activos de empresas

* Este trabajo se inscribe en el proyecto Fondecyt Regular № 1150182 ("La subordinación legal de créditos en la nueva legislación concursal").

** Profesor de Derecho Civil de la Facultad de Derecho de la Pontificia Universidad Católica de Chile. Doctor en Derecho, Universidad de Salamanca. Dirección postal: Av. Libertador Bernardo O'Higgins № 340, Santiago. Correo electrónico: jgoldenb@uc.cl. 
y personas (en adelante, "LRLAEP"), se refiere a un nuevo sistema revocatorio concursal, contenido en su Capítulo VI. Si bien son varias las reformas que vale la pena apuntar en este aspecto, el presente trabajo se centrará en sólo una de ellas, referida a la comprensión del perjuicio. Lo anterior, porque, como bien resume Puga, "sin perjuicio no hay revocación"1.

Así, este elemento se establece como el pivote sobre el cual se articula todo el régimen de revocación, puesto que sólo por medio de éste logra identificarse su finalidad en el marco de los procedimientos concursales, como una herramienta dependiente para el cumplimiento de su objetivo esencial: la mejor tutela del crédito mediante el aumento de las posibilidades de satisfacción ${ }^{2}$. En este sentido, será la constatación del perjuicio la que modelará los efectos de la revocación, que, en nuestro sistema, se articulará como un mecanismo de reintegración o depuración patrimonial, según el caso ${ }^{3}$.

Entonces, debemos iniciar el presente trabajo dando cuenta que el elemento del perjuicio que se presenta en toda formulación de las acciones revocatorias concursales, especialmente a nivel patrio, se elabora sobre la base de las consecuencias nocivas del acto o contrato que pretende ser revocado (eventus damni ${ }^{4}$ y de la identificación de aquello que, directa o indirectamente, recibe dicho perjuicio.

Estos aspectos estaban sujetos a discusión en el ámbito del Libro IV del Código de Comercio. Al respecto, la ausencia de una referencia expresa a dicho elemento en el texto legal había dado cuenta de una jurisprudencia errática, ahí donde se presentaban una serie de dudas respecto a la efectiva utilización de estas herramientas de reintegración patrimonial ${ }^{5}$. Así, nuestros tribunales se

\footnotetext{
1 Puga (2014), p. 439.
}

${ }^{2}$ Aunque Puga (2014), p. 432, se refiere a la dependencia de estas acciones desde una perspectiva eminentemente procesal, hacemos referencia a ella desde un punto de vista esencialmente finalista. La finalidad de las acciones revocatorias concursales, que pretenden una recomposición del patrimonio del deudor, puede entenderse en el marco general de un diseño concursal que pretende aumentar los niveles de satisfacción de los acreedores. Como indica JACKSON (1986), p. 125, esta clase de reglas pretende reintroducir el problema de la tragedia de los recursos comunes a efectos de enfrentar la planificación estratégica en un período preconcursal, y, como propuesta de solución a estos conflictos, la ineficacia pretende redistribuir los beneficios y sacrificios de las partes en clave colectiva en miras a la eficiencia común.

${ }^{3}$ Como señala León (2004), p. 1299, aunque en el contexto del Derecho español, "[L]a ineficacia del acto o contrato no trata de proteger a una de las partes de ese acto o contrato, sino a terceros, los acreedores de una de esas concretas partes; y esa específica tutela se justifica por el carácter perjudicial que ese acto o ese contrato comporta para la comunidad crediticia".

${ }^{4}$ Sanjuán (2012), p. 134.

${ }^{5}$ Contador y Palacios (2015), p. 291. 
habían pronunciado identificando que este elemento subyacente a la acción estaba dado por el perjuicio a la denominada par condicio creditorum $^{6}$; a los bienes de la masa concursal, en búsqueda de ejecutar el patrimonio teórico que el deudor hubiese tenido al momento de la cesación de pagos ${ }^{7}$, o, incluso, directamente en perjuicio a los acreedores ${ }^{8}$. También se ofrecieron fórmulas mixtas, tales como el resguardo del patrimonio del deudor $y$, con ello, la seguridad de pago del crédito que a él se le otorgue, en alusión a la regla de responsabilidad patrimonial universal ${ }^{9}$.

En materia doctrinal, el punto era especialmente tratado por Puga, quien entendía que el aspecto a apreciar se encontraba siempre en la vulneración de la par condicio $^{10}$, que se incardinaría como un "principio sustantivo de derecho privado, pero de orden público, que el legislador no quiere que sea vulnerado ni dentro ni fuera del concurso"111; y por Vargas, quien, identificando este elemento en la acción pauliana civil y en las revocatorias, entendía que "la única manera de perjudicar a los acreedores consiste en crear o agravar la insolvencia del deudor, porque ello repercute en el patrimonio de éstos haciendo que no sean pagados o que lo sean sólo en parte"1212. Alternativamente, Gómez y Eyzaguirre ${ }^{13}$, y Contreras ${ }^{14}$ parecían referirse a tal elemento por el propósito general del restablecimiento del activo o el reintegro a la masa de los bienes dispuestos en fraude de sus acreedores. Y, finalmente, Puelma se pronunciaba en razón del perjuicio

\footnotetext{
${ }^{6}$ Así, por ejemplo, en Sentencia de la Corte Suprema, Rol 2312-2003, de 27 de julio de 2004, refiriéndose a la inoponibilidad de una prenda constituida para garantizar obligaciones preexistentes.

7 Así, por ejemplo, en sentencia de la Corte Suprema, Rol 15988-2013, de 15 de enero de 2015, refiriéndose a la pretendida inoponibilidad de un pago efectuado por un tercero, que luego entró en cesación de pagos y fue declarado en quiebra.

${ }^{8}$ Así, por ejemplo, en sentencia de la Corte Suprema, Rol 10253-2013, de 15 de marzo de 2015, refiriéndose a la inoponibilidad de la venta de derechos sobre un inmueble y de un inmueble, en ambos casos, en sumas inferiores al avalúo fiscal; en sentencia de la Corte Suprema, Rol 8654-2012, de 24 de diciembre de 2012, relativa a la inoponibilidad de varias compraventas de productos de tuberías y maquinarias del activo fijo de la empresa; y en sentencia de la Corte Suprema, Rol 2059-2011, de 27 de septiembre de 2011, refiriéndose a la inoponibilidad de un aporte en dominio de un inmueble a una sociedad.

${ }^{9}$ Así, por ejemplo, en sentencia de la Corte Suprema, Rol 180-2011, de 31 de octubre de 2012, refiriéndose a la inoponibilidad de un contrato de compraventa de un inmueble.

10 Puga (2004), p. 454. En el nuevo régimen concursal, Puga (2014), p. 431.

11 Puga (2004), p. 458. En el nuevo régimen concursal, Puga (2014), p. 437.

12 VARGAS (1949), p. 374.

13 Gómez y Eyzaguirre (2011), p. 249.

${ }^{14}$ Contreras (2010), p. 189.
} 
a los intereses de los acreedores por actos ejecutados por el fallido en el período sospechoso que antecedía a la quiebra ${ }^{15}$.

Por su parte, la formulación del elemento del perjuicio se ha presentado de manera dispar en otros ordenamientos jurídicos ${ }^{16}$. Así, por ejemplo, en los ordenamientos italiano, alemán y argentino, el punto focal estará dado por el perjuicio a los acreedores (artículos 66 de la Legge Fallimentare ["LF"], §69 de la Insolvenzordnung ["InsO"] y 119 de la Ley $\mathrm{N}^{\circ} 24.522$, de concursos y quiebras ${ }^{17}$, respectivamente) ${ }^{18}$. En el Derecho español, por su parte, éste se centra en el perjuicio a la masa activa (artículo 71 de la Ley Concursal [“LC"]). $\mathrm{Y}$, finalmente, en el Derecho colombiano, hay referencia al perjuicio a cualquiera de los acreedores o a la afectación del orden de prelación de los pagos y cuando los bienes que componen el patrimonio de deudor sean insuficientes para cubrir el total de los créditos reconocidos (artículo 74 de la Ley $\mathrm{N}^{\circ} 1.116$, de insolvencia empresarial $)^{19}$.

En todo caso, y no obstante la estructura particular que pueda presentar cada redacción normativa, parece indudable que el ejercicio de las revocatorias concursales tiene por principal finalidad la ampliación de masa activa disponible para la satisfacción de los fines del procedimiento concursal ${ }^{20}, \mathrm{o}, \mathrm{al}$ menos, depurar dicha masa de los gravámenes que pudieron haberse constituido produciendo una alteración de la posterior aplicación de las reglas de prelación

\footnotetext{
15 Puelma (1971), p. 122.
}

${ }^{16}$ En la Guía Legislativa sobre el Régimen de la Insolvencia de Comisión de las Naciones Unidas para el Derecho Mercantil Internacional (CNUDMI) de 2004 ya se expresa que "Estas disposiciones están destinadas a invalidar toda operación anterior en la que haya intervenido el deudor insolvente o que tenga ciertos efectos para los bienes del deudor, concretamente que reduzcan el valor neto de su patrimonio (por ejemplo, cuando éste done bienes o los transmita o venda a un precio inferior a su justo valor comercial) o que violen el principio de la igualdad con que debe tratarse a todos los acreedores de una misma categoría (por ejemplo, pagando una deuda a un determinado acreedor no garantizado o constituyendo una garantía real a favor de un acreedor que no disponga de ninguna, mientras que otros acreedores ordinarios siguen sin cobrar y sin garantías)" CNUDMI (2004), p. 162.

${ }^{17}$ Como indica Pesaresi (2003), pp. 35 y 36, la incorporación del elemento de perjuicio de manera expresa en la ley concursal argentina debe ser considerado como un avance respecto a la ley anterior (Ley $\mathrm{N}^{0}$ 19.551), en que, sólo por medio de una interpretación doctrinal y jurisprudencial, se había configurado el eventus damni como un requisito esencial para la procedencia de la acción.

${ }^{18}$ En el Derecho francés, aunque los artículos L. 632-1 a L. 642-4 del Código de Comercio no se refieran específicamente al elemento del perjuicio, se ha entendido que la revocación se justifica en la organización o incremento fraudulento de la insolvencia o en el restablecimiento del tratamiento igualitario de los acreedores. JACQUEMONT (2013), p. 355.

${ }^{19}$ Para una noción extensiva del perjuicio o daño directo a los acreedores en el Derecho colombiano, Sotomonte (2014), p. 271. A su vez, para una crítica a la redacción del artículo, RodríGuez (2007), pp. 528 y 529 .

20 Bermejo (2002), p. 87. 
de créditos $^{21}$. Pero, como nos señala García-Cruces, el diseño de cualquier sistema de reintegración patrimonial en el caso de concurso debe ponderar la legítima tutela de los intereses comunes de los acreedores, con la seguridad en el tráfico jurídico. Y, conforme explica, ello se sustenta esencialmente en la adecuada asignación de lo que denominaremos "riesgo de revocación", por medio de un sistema de información que permita al tercero en cuestión ponderar la posibilidad de que, en razón de la eventual apertura del concurso (que, al tiempo de la celebración del negocio jurídico, resulta aún incierta), se ocasionen una serie de consecuencias basadas en la revocación del acto ${ }^{22}$. Dicho sistema informativo, en el punto que nos interesa, debe tener un grado de precisión respecto al elemento del perjuicio del que tratamos, que, conforme a la construcción de todo sistema de reintegración, se encuentra presente a modo de justificación de la posibilidad de revisión de aquellos actos que, de no existir una situación de crisis patrimonial, serían considerados plenamente válidos y eficaces por parte del ordenamiento jurídico ${ }^{23}$.

Considerando todo lo anterior, por medio del presente estudio pretendemos dar cuenta de cómo se ha abordado este aspecto en el marco de la LRLAEP. Lo anterior, bajo la hipótesis que este elemento no recibe un planteamiento unívoco en las diversas acciones revocatorias consagradas en su Capítulo VI, para, a partir de ello, explicar la diversidad de reacciones jurídicas dependientes de su configuración. Para efectos de lograr lo anterior, el presente trabajo se articula del siguiente modo: en primer término, revisando la construcción del perjuicio a la masa pasiva y, luego, revisando como perjuicio a la masa activa, y, en ambos casos, dando cuenta de las reacciones del ordenamiento para lograr la reintegración patrimonial a partir de la constatación de dicho requisito y sus consecuencias en la asignación del riesgo de revocación.

\section{El perjuicio a la masa pasiva}

\subsection{Elaboración conceptual}

La construcción normativa de la acción revocatoria se incardina en los objetivos propios del procedimiento concursal, no siendo un elemento exógeno

\footnotetext{
${ }^{21}$ En este sentido, la Guía Legislativa CNUDMI (2004), p. 162, agrega que "Las disposiciones que regulan las facultades de anulación tienen la finalidad de apoyar esos objetivos colectivos, asegurando que los bienes de un deudor insolvente se distribuyan equitativamente entre los acreedores con arreglo al orden de prelación establecido y preservando la integridad de la masa de la insolvencia".

22 García-Cruces (2012), p. 122. Para una breve justificación histórica sobre el punto, véase Nigro y VATTERMOLI (2009), p. 162.

${ }^{23}$ CNUDMI (2004), p. 163.
} 
a sus finalidades. Como nos enseña la doctrina económica (reflejada, a su vez, en la reacción legislativa), la crisis patrimonial traslada el concepto de propietario residual (residual owner) del deudor (o sus socios o accionistas, según el caso) al conjunto de acreedores. Lo anterior aparece evidente en los casos en que se ha dado inicio a un procedimiento concursal formal, produciendo un traslado de dichas facultades a los órganos concursales (en nuestro sistema, artículo 130 LRLAEP), o una limitación al ejercicio de ciertos actos dominicales (artículos 57.2 y 264.6 LRLAEP). Pero aún ha quedado un espacio entre el tiempo en que se ha dado lugar a la señalada crisis y el momento mismo de la apertura del concurso ${ }^{24}$, en que las facultades de administración y disposición de los bienes todavía parecen sujetarse a las reglas generales de locación del riesgo en el mismo deudor. La revisión de los actos ejecutados en un período de sospecha no hace sino extender la lógica concursal, dada por la maximización de las posibilidades de cobro de los acreedores, para la revisión de los actos ejecutados o contratos celebrados por el deudor ${ }^{25}$, valorando si, abierto el concurso, han producido o no un desajuste en tales pretensiones satisfactorias.

Entonces, si apreciamos que la finalidad del concurso se construye en torno al concepto de eficiencia y a la maximización de las posibilidades de cobro de los acreedores ${ }^{26}$, resultará que su interés común, aun en una dimensión hipotética ${ }^{27}$, implicará que el perjuicio del cual hablamos se centre en valorar las consecuencias del acto o contrato impugnado en el logro de dicho parámetro económico. Por ello, cuando aludimos al perjuicio a la masa pasiva en el contexto de las acciones revocatorias concursales, estamos refiriéndonos a la frustración de aquel afán de eficiencia como consecuencia de un acto ejecutado o de un contrato celebrado por el deudor en una etapa preconcursal, y que ha implicado, ya en el contexto del concurso, una disminución del valor relativo de los créditos.

En este sentido, la fundamentación de las acciones revocatorias en la noción objetiva del perjuicio a los acreedores da cuenta de una finalidad distributiva, lo que, en el ámbito comparado, ha sido observado como una lesión in re ipsa, sin necesidad de dar cuenta de un daño en concreto al conjunto de acreedores más allá de la lesión al crédito, que no esté dado simplemente por el perfeccionamiento de un acto que lesiona la posibilidad liquidativa o satisfactoria de

\footnotetext{
${ }^{24}$ Mokal (2005), pp. 306-307.

25 Ambrosini (2000), p. 2.

${ }^{26}$ En general, TIRADO (2009).

27 Goldenberg (2015), p. 211.
} 
la masa de acreedores o la afectación a la par condicio creditorum ${ }^{28}$. De este modo, se rechaza una dimensión estrictamente indemnizatoria de la acción revocatoria ${ }^{29}$, puesto que, además de no necesitar de un elemento de atribución dolosa o culpable del resultado (esto es, una intención fraudatoria), tampoco requiere de la acreditación de un perjuicio en concreto que deslinde la extensión de la reparación. La revocación del acto o contrato se dará in totum, aunque convenga dar cuenta de los efectos que tal medida pueda tener en relación con las eventuales contraprestaciones que pudieron haber sido realizadas por el tercero.

Todo lo anterior implica que, a efectos de valorar esta suerte de perjuicio, deba efectuarse una proyección de los resultados del acto cuestionado, a pesar de haberse ejecutado en una etapa anterior al concurso, en las posibilidades satisfactorias del conjunto de acreedores una vez abierto, y en su incidencia en la determinación del valor relativo de los créditos. Así, se entenderá que aquél resulta en un acto perjudicial en caso que éste produzca un desmembramiento irregular de los bienes del deudor, destruya la integridad de las unidades económicas o distorsione la lógica distributiva del concurso en atención a la futura aplicación de las reglas de prelación de créditos $^{30}$.

Puga, al contrario, sostiene que los legitimados pasivos podrían acreditar la ausencia de perjuicio "mediante la prueba de que al tiempo de ejecutarse el acto el deudor no era insolvente" ${ }^{\prime \prime 3}$. Sin embargo, creemos que esta solución no es posible, puesto que la afectación no está dada, como veremos, ni por la creación o agravamiento de la insolvencia en razón del acto, ni éste podrá ponderarse en sus resultados a los acreedores al tiempo de su ejecución, ya que, en este punto temporal, aún no hay masa de acreedores ni intereses colectivos que puedan resultar perjudicados.

En este punto, la afectación a los acreedores no debe observarse únicamente respecto a los resultados económicos que ocasiona el acto en el patrimonio del deudor, si no es para verificar en especial el atentado a la lógica concursal en el sistema antes descrito. Hay, en este sentido, una revisión de la regla de

\footnotetext{
28 PaluChowski (2013), pp. 737-738. Para una visión crítica del concepto de la par condicio creditorum, en general, GOLDENBERG (2010).

${ }^{29}$ En el Derecho italiano, la interpretación de la naturaleza de la acción revocatoria en este sentido se habría basado, en primer término, en razón de su construcción como una especie dentro del género de la revocatoria ordinaria dispuesta en el artículo 2901 del Codice civile, Nigro y Vattermol (2009), p. 162.

${ }^{30}$ En este sentido, al igual como se presenta en otros ordenamientos, como el alemán ( $\$ 129$ InsO), el concepto de perjuicio a los acreedores es lo suficientemente amplio y elástico como para pretender la revocación de cualquier acto significativamente relevante en la incidencia en sus derechos personales, RogGe y LePtien (2012), p. 1212.

31 Puga (2014), p. 431.
} 
responsabilidad patrimonial universal (artículo 2465 CC), pero observada en clave concursal y orientada a la satisfacción realizada en aplicación de las reglas de justicia distributiva que imperan en el contexto concursal ${ }^{32}$.

\subsection{El perjuicio a la masa pasiva en los supuestos de revocación objetiva}

Los artículos 287 y 290 LRLAEP (este último, en sus tres primeros incisos) tratan de la revocación objetiva de los actos ejecutados o de los contratos celebrados por la empresa deudora o la persona deudora, respectivamente, con anterioridad al inicio de un procedimiento concursal. Las normas aplicables se presentan con un claro paralelismo, en que las únicas diferencias constatables están dadas por la legitimación activa ${ }^{33}$ y por la extensión de la asimilación a los actos a título gratuito de los pagos anticipados de deudas ${ }^{34}$.

Ahora bien, conforme al tenor de ambas normas, el éxito en el ejercicio de la acción requiere de la constatación de tres elementos: (i) que el acto o contrato se conforma a la tipología de la revocación objetiva, integrada por los actos a título gratuito y otros actos asimilados (llamados también "obsequiosos") ${ }^{35}$; (ii) la celebración del acto o contrato en el arco temporal de uno o dos años previos al inicio del procedimiento concursal, período que dependerá del tipo de acto a revocar y de su celebración con quienes integran la definición de personas relacionadas al deudor ${ }^{36} ;$ y (iii) el perjuicio a los acreedores.

${ }^{32}$ Es en este sentido, por ejemplo, en el que se ha dado lectura a la idea de los efectos de la quiebra (fallimento) respecto de los actos perjudiciales a los acreedores, dispuesta en el artículo 67 LF italiana, bajo la idea de la función redistributiva (y no indemnizatoria) de las acciones revocatorias, RosAPEPE (2013), p. 247.

${ }^{33}$ En la revocación objetiva de los actos ejecutados y contratos celebrados por la persona deudora con anterioridad al inicio del procedimiento, la legitimación activa se refiere únicamente a los acreedores, ignorando la posibilidad de actuación por medio del liquidador, en el ámbito del procedimiento concursal de liquidación de bienes (artículos 273 y siguientes LRLAEP).

${ }^{34}$ En el caso del pago anticipado de las deudas, el artículo 290 LRLAEP no establece la asimilación al descuento a los efectos de comercio, como ocurre en el caso del artículo 287.I.1 LRLAEP, en referencia a la empresa deudora. Lo anterior se justifica en que esta clase de operaciones son difícilmente realizables por el sujeto pasivo del que tratamos, puesto que éste se configura como una persona natural que realiza un trabajo dependiente o no obtiene rentas que den lugar al pago del impuesto a la renta. Lo que sí llama la atención, es que tampoco existe una asimilación del pago anticipado con aquél en que el deudor haya renunciado al plazo en su favor, aunque entendemos que el pago así configurado puede ser igualmente revocado acudiendo al expediente del fraude a la ley. En similar sentido, ConTADOR Y PALACIOS (2015), p. 292.

35 PugA (2014), p. 431.

${ }^{36}$ Obsérvese que en toda la nueva normativa concursal la fijación del denominado "período sospechoso" no hace referencia a una específica fecha de cesación de pagos, como se establecía en el modelo previsto en el Libro IV del Código de Comercio, de manera que este elemento, al menos 
Sobre este último aspecto, que constituye el núcleo de esta investigación, cabe advertir que no se trataba de un elemento expresamente integrado en la fisonomía que quería darse a la revocación objetiva en el mensaje de la LRLAEP ${ }^{37}$. Al contrario, se presentaba una acción en la que la constatación o ausencia del perjuicio parecía indiferente para el texto normativo, asumiendo que la sola naturaleza del acto era suficiente justificación para fines de revocación ${ }^{38}$. De este modo, si es que acaso se entendía subyacente al acto, el perjuicio parecía justificarse en una doble noción. Primero, en el detrimento a la masa activa en aquellos actos propiamente gratuitos, donde el título de la disposición patrimonial de un activo (véase en general, donación) o el acto de extinción de un crédito (véase, en general, remisión de deuda) producían una reducción del patrimonio del deudor basado en su mera liberalidad y no justificado por una contraprestación; o en las daciones en pago de deudas, probablemente asumiendo un mayor valor del bien entregado, en relación con el importe de la obligación extinguida por esta vía. Y, segundo, en la existencia de un perjuicio a la masa pasiva, por el alejamiento de las normas de prelación de créditos, para el caso que se hubiese llevado a cabo un pago anticipado de la deudas o se hubiese constituido un derecho de garantía que otorgase preferencia para el

en el caso de la revocación objetiva, no puede tratarse como un "período de cesación de pagos" SANDOVAl (2014), p. 256, sino solo como una limitación temporal dada en razón de la seguridad y estabilidad de los negocios jurídicos. En este sentido, creemos que esta nueva regulación impide que hablemos propiamente de retroacción del concurso (en contra, SANDoval (2014), pp. 253 y 255). Lo anterior, porque ello es propio del modelo recogido del Code de Commerce francés, en que se pretende igualar los efectos de los actos ejecutados después de la apertura del concurso (nulidad), con aquellos que se habían llevado a cabo con anterioridad a ella y desde la fecha de cesación de pagos, excepciones en materia de actos onerosos a efectos de facilitar el tráfico jurídico. JACQUEMONT (2013), p. 335; PÉROCHON (2014), p. 671.

${ }^{37}$ Si bien el mensaje inicialmente disponía que en estos casos había una presunción de perjuicio en relación con los actos objetivamente revocables (Historia de la Ley $\mathrm{N}^{\circ} 20.720$, p. 13), el texto daba a entender que el perjuicio en realidad no era parte de los supuestos de la acción. De tal suerte, el texto original disponía que "En las demandas que se deduzcan de conformidad a lo establecido en este artículo, el juez se limitará a constatar si el acto ejecutado o el contrato celebrado han tenido lugar dentro de los plazos señalados y si responden a alguna de las descripciones previstas, sin atender a la existencia o no de perjuicios que el acto o contrato pudiera haber causado a los acreedores o a terceros" (el destacado es nuestro).

${ }^{38}$ En similar sentido se había expresado nuestra jurisprudencia al amparo de la regulación de las acciones revocatorias concursales en el Libro IV del Código de Comercio, especialmente en referencia al artículo 76 de dicho cuerpo legal, que regulaba de una de las denominadas "inoponibilidades de derecho", al tratar de los actos ejecutados por el deudor a título gratuito. En este sentido, nuestra Corte Suprema había señalado que en estos casos "no será necesario comprobar la concurrencia de perjuicio patrimonial efectivo para los acreedores, pues éste se presume iuris et de iure, sin admitir prueba en contrario", haciendo referencia al carácter gratuito del acto en cuestión. Sentencia de la Corte Suprema, Rol 11587-2014, de 15 de enero de 2015. 
pago de una obligación que no estaba previamente asegurada en un período demasiado cercano al inicio del procedimiento concursal.

La referencia expresa al elemento del perjuicio se dio mediante una incorporación al texto en el primer trámite legislativo de la LRLAEP, a instancias del Honorable Senador Espina ${ }^{39}$, a fin de matizar el efecto de las acciones de revocación allí donde los actos o contratos resultasen inocuos para los acreedores $\mathrm{O}$, incluso, beneficiosos para ellos. En razón de lo anterior, el inciso tercero de los artículos 287 y 290 LRLAEP, dispone que "Habiéndose constatado la concurrencia de los requisitos anteriores, el tribunal dictará sentencia acogiendo la acción revocatoria concursal interpuesta, salvo que el Deudor o el tercero contratante acrediten que el acto ejecutado o el contrato celebrado no produjeron perjuicio a la masa de acreedores".

A partir de esta norma, podemos Ilamar la atención de tres observaciones. La primera, que se presenta de modo más evidente, es que si bien se ha incorporado expresamente el perjuicio como requisito de las acciones de revocación objetiva, éste se encuentra sujeto a un régimen de presunción simplemente legal ${ }^{40}$. Esta decisión legislativa parece basarse en la idea expresada en el texto original de la norma, en el sentido que la propia tipología de los actos será generalmente indiciaria del perjuicio, por lo que podría resultar innecesaria su comprobación por parte de los legitimados activos, pero deja una puerta abierta para aquellos supuestos en el que el acto o contrato no lesione las pretensiones de cobro de los acreedores, procediendo en este caso la prueba del deudor o del tercero contratante en tal sentido ${ }^{41}$.

\footnotetext{
${ }^{39}$ Al efecto, la Historia de la Ley $N^{\circ} 20.720$, p. 885, da constancia que el Honorable Senador Espina "observó que no todo pago anticipado u otras figuras contempladas por esta norma son necesariamente perjudiciales. Por ejemplo, añadió, un pago anticipado puede ser beneficioso. Por ello, estimó necesario reconsiderar la exclusión de la prueba de los perjuicios -o de los beneficios según sea el caso-, de este cuadro". A partir de dicha intervención, posteriormente apoyada por los Honorables Senadores Zaldívar y Larraín, se motivó a la modificación del texto en el sentido de generar una presunción simplemente legal de la existencia de perjuicio, de manera que se permitió que el deudor o el tercero contratante acreditasen su ausencia en el caso concreto (Historia de la Ley № 20.720, pp. 885-888), replicándose asimismo en el caso de la revocación objetiva de los actos y contratos celebrados por la persona deudora.

${ }^{40}$ En otros ordenamientos, tales como el español (artículo 71.2 LC), este tipo de actos da lugar a presunciones de derecho, fundados particularmente en que el perjuicio se aprecia en torno a una afectación a la masa activa, cuestión que no es coincidente con el sistema chileno en el aspecto que tratamos. En nuestro entorno, VARGAS (1949), p. 375, entendía que el daño también estaba sujeto a una presunción simplemente legal, pero, dado que entendía que éste se refería a la creación o agravación de la insolvencia, la prueba recaería sobre la suficiencia del patrimonio para la satisfacción de todos los créditos que forman parte de la masa.

${ }^{41}$ En este sentido, Contador y Palacios (2015), p. 291, señalan que la revocación objetiva trata de "un conjunto de actos o contratos, cuya ejecución o suscripción teóricamente son dañinos para los acreedores".
} 
La segunda consecuencia es que, en el ámbito de este tipo de acciones, podremos distinguir "actos perjudiciales" y "actos no perjudiciales", siendo únicamente los primeros aquellos que podrán ser finalmente revocados por el tribunal. En este caso, el acto perjudicial se presenta como una regla general al adscribirse a la tipología antes indicada, presumiendo que en él se evidencia un detrimento a las posibilidades de cobro de los acreedores o una lesión a las reglas de justicia distributiva que imperan en el concurso. Al contrario, la calificación del acto como "no perjudicial" resulta precisamente de la valoración de la prueba presentada por los legitimados pasivos (el deudor y los terceros contratantes), que logran desacreditar la existencia de un verdadero perjuicio a la masa pasiva, a pesar de la adscripción del acto a la tipología prevista en las normas en comento y a su ejecución o celebración dentro del período de sospecha previsto para cada caso.

Asimismo, la referencia al acto perjudicial supone la realización de un juicio de valor ex post por parte del tribunal. De este modo, no se integran elementos subjetivos que determinen la existencia de un animus nocendi por parte de los intervinientes al acto, especialmente si se considera que el perjuicio del que trata la norma se revisará en un momento posterior, que no es necesariamente conocido por aquéllos, como es el que se refiere precisamente a la situación de crisis patrimonial y al consecuente inicio de un procedimiento concursal ${ }^{42}$. Supone, asimismo, que no existe un "elemento finalista del acto anterior que se rescinde; es decir, no es necesario que ese acto por sí o junto a otros haya motivado, generado o agravado la insolvencia" ${ }^{\prime 4}$.

Por último, la noción de perjuicio destacada por la norma se refiere expresamente al daño a la masa pasiva, esto es, al conjunto de acreedores. De este modo, al igual como se ha presentado en el ámbito del Derecho comparado, la elaboración del concepto de perjuicio a los acreedores no se encuentra definido por el legislador, por lo que deberá analizarse el efecto que ocasiona el acto en la hipotética cuota de satisfacción de los acreedores ${ }^{44}$, efectuando un ejercicio comparativo entre la situación en la que se encontrarían los acreedores si no se hubiese llevado a cabo el acto o contrato en cuestión. A nuestro juicio, esta referencia implica que, para la calificación del acto como no perjudicial, los

\footnotetext{
${ }^{42}$ Conforme a ello, debería rechazarse la tesis de VARGAS (1949), pp. 345-349, quien elabora la justificación de las acciones revocatorias en la confianza depositada por los acreedores en su deudor y en el principio de buena fe. De este modo, no podría indicarse que su base se encuentra en que "[E]I deudor abusa de este derecho cuando lo ejerce fraudulentamente, contrariando su fin económico y social, con la intención de perjudicar a sus acreedores".

43 Sanjuán (2012), p. 134.

${ }^{44}$ Pons Albentosa (2012), p. 37.
} 
legitimados pasivos de la acción deberán comprobar que, por medio de una proyección de las consecuencias del acto o contrato en el valor relativo de los créditos concursales, las posibilidades de satisfacción de los acreedores no se han visto alteradas, o, incluso, han sido mejoradas a la que se hubiesen logrado en su ausencia. En otras palabras, el estándar probatorio debe estar dado por los resultados económicos del acto en cuestión, no bastando una referencia puntual a las consecuencias que el mismo pudo haber tenido en el patrimonio del deudor, que, para estos efectos, sólo podría redundar en un elemento incidental o indirecto para la elaboración del argumento.

De este modo, esta noción de perjuicio se comportará de manera diversa dependiendo del acto o contrato que se pretende revocar.

Si éste se refiere a aquellos actos que, como indicamos precedentemente, suponen una afectación a las normas de prelación de créditos, como resultado de los criterios de justicia distributiva, el perjuicio a la masa pasiva parece darse en razón de la propia tipología del acto. En este sentido, creemos que habrá poca cabida para la calificación de los pagos anticipados de las deudas ${ }^{45} \mathrm{o}$ la constitución de garantías reales para asegurar obligaciones preexistentes como actos no perjudiciales (garantías no contextuales) ${ }^{46}$. Esta conclusión se sujeta a que, efectuada la proyección por parte del tribunal, ambos hechos tengan por consecuencia la disminución de las posibilidades de pago por parte de la masa de acreedores. En el primer caso, porque el pago previo implicará que el correspondiente acreedor ni siquiera estaría participando en el procedimiento concursal habida cuenta de la extinción previa de la deuda, de manera que no entraría en el juego de los repartos del activo conforme a las normas de prelación. Y, en el segundo, porque la constitución de la garantía real alterará necesariamente el valor relativo de los créditos al asignar una preferencia que antes no existía, y que, por tanto, probablemente hubiese calificado al crédito como valista ${ }^{47}$.

45 Sandoval (2014), p. 264; Contador y Palacios (2015), p. 292.

46 Sandoval (2014), p. 265; Puga (2014), p. 435.

${ }^{47}$ En este sentido, Puga (2014), p. 464. En contra, Contador y Palacios (2015), p. 295, otorgan ciertos ejemplos adicionales, como el pago anticipado de un crédito con una tasa muy alta, cuyo acreedor la reduce, aceptando además el pago con una condonación o remisión de parte del capital, o la constitución de garantías para asegurar el cumplimiento de obligaciones anteriormente contraídas, cuando el acreedor aumenta sus líneas de crédito, rebajando además las tasas de interés de la obligación primitiva. Si bien nos parece que los mencionados ejemplos son posibles, igualmente deberá atenderse a la situación en la que se encontrarían los acreedores en razón de la proyección del acto, el que no siempre será favorable. Por de pronto, en el último caso planteado, la ampliación de las líneas de crédito puede haber resultado inocua (o, incluso, perjudiciales) para los acreedores en razón del aumento del endeudamiento, al tiempo que la sola reducción de la tasa de interés podría también 
En el caso de los actos o contratos puramente gratuitos, como las donaciones y remisiones de deuda, resultará evidente que se ha producido un perjuicio patrimonial, dado por la salida de los bienes del deudor de su patrimonio o por una reducción de sus activos por vía de la extinción de sus créditos. Pero, dada la fórmula de perjuicio reflejada en las normas en comento, el acto podría ser calificado como no perjudicial si, efectuada la proyección antes indicada, no haya una verdadera alteración a las posibilidades de pago de los acreedores. Ello podría darse, por ejemplo, si la donación hubiese recaído sobre un bien de escaso valor (como las donaciones proporcionales a las fuerzas del patrimonio, aceptadas en el ordenamiento en razón de los usos sociales, véase en general, en el artículo $1735 \mathrm{CC})^{48}$, o que la deuda remitida hubiese tenido escasísimas posibilidades de pago (por ejemplo, por tratarse de una obligación natural), de manera que el acto resulte completamente superfluo ${ }^{49}$.

Por último, tratándose de daciones en pago, la proyección se referirá, en primer término, a la valoración del bien entregado para la satisfacción de la deuda. De este modo, si se comprueba la identidad de valores o, incluso, que la deuda era por un importe superior al valor del bien, resultará que, en principio, no habría afectación a las pretensiones de cobro de los acreedores. Sin embargo, dada la dimensión de perjuicio antes explicada, el acto todavía podría tener un carácter perjudicial, aun cuando el valor del bien sea igual o inferior, si se trataba de un bien esencial para el desarrollo de las actividades del deudor o integraba crucialmente su unidad económica ${ }^{50}$. En este caso, la noción de perjuicio también posibilitaría constatar su existencia puesto que, en la proyección puede asimismo considerarse la posibilidad que, de no haberse ejecutado el acto o contrato, la empresa podría haberse sometido efectivamente a una reorganización concursal; o, ya en un escenario de liquidación, que la realización podría haberse llevado a cabo en consideración a dicha unidad,

\footnotetext{
resultar insuficiente si consideramos que, en el caso de un escenario de liquidación, éstos quedarán pospuestos al pago a partir de la dictación de la resolución de liquidación (artículo 139.V LRLAEP).

${ }^{48}$ En similar sentido, puede leerse la §134.2 InsO.

${ }^{49}$ Por ello, creemos que la justificación dada por Contador y Palacios (2015), p. 294, basada en la idea de la subrogación real, puede resultar demasiado estricta en este ámbito. Si la locación de la norma se situase en un perjuicio a la masa activa (similar al que se propone en el artículo 288.2 LRLAEP), creemos que la conclusión sería admisible, pero el artículo 287 LRLAEP está haciendo precisamente referencia al perjuicio a los acreedores. Conforme a lo anterior, no es suficiente la ausencia de un valor que ingrese a la masa pasiva, sino que el acto en sí provoque una afectación en los derechos de cobro de los acreedores.

${ }^{50}$ Como señala Puga (2014), p. 463, la dación en pago puede haber importado una falta de liquidez de parte del "fallido", lo que pudo haber derivado, en el ejemplo, en la entrega de bienes que resultaban operativos para el deudor.
} 
sea por medio de las reglas de enajenación como unidad económica (artículos 217 y siguientes LRLAEP), oferta directa (artículos 222 y siguientes LRLAEP) o cualquiera otra acordada por los acreedores (artículo 207 LRLAEP) ${ }^{51}$.

Por su parte, si revisamos todas estas consecuencias desde la perspectiva de la asignación del riesgo de revocación al tercero contratante o a quien ha recibido el pago de las obligaciones en la tipología de los actos obsequiosos, resultará que el ámbito de información recibido por aquél se centrará en la identificación de los actos que por esencia resultan sospechosos y en la posibilidad que éste tenga de anticipar la proyección de sus resultados en un eventual escenario concursal. Carente de todo elemento subjetivo, resultará entonces indistinto si el tercero ha tenido o no un real conocimiento de la situación patrimonial del deudor al tiempo de la realización del acto, o, incluso, si puede anticipar una pronta apertura del concurso, por lo que dichas ponderaciones deberán efectuarse con independencia a los exámenes que pudo haber anticipado o no como medida de resguardo ${ }^{52}$.

Siendo de este modo, nos parece que el citado riesgo se encuentra aquí correctamente asignado a dicho tercero, en tanto no parece producir un elemento que dificulte enormemente el tráfico jurídico ${ }^{53}$. En el caso de los actos típicamente gratuitos, la posibilidad de revocación, a lo sumo, provocará la pérdida del bien que le ha sido asignado, pero la propia liberalidad que ha justificado el acto provocará que la balanza ceda en beneficio de los intereses de los acreedores (favor concursus). Así, sea que nos encontremos frente a una donación o una remisión de deuda, la retroacción de las partes al estado al que

\footnotetext{
${ }^{51}$ A diferencia de SANDOVal (2014), p. 264, creemos que en nada incide en este análisis un elemento subjetivo (mala fe) por parte del acreedor en razón del citado desequilibrio. La revocación objetiva, como su nombre lo indica, carece en su construcción de todo elemento que pueda centrarse en un juicio de reproche basado en el ánimo del deudor o del tercero.

52 Para Sandoval (2014), p. 263, no se exige el elemento de mala fe de los contratantes ya que esta clase de actos, por su propia naturaleza, permitirían presumirla, aunque ello no se indique de manera expresa en la normativa aplicable. A nuestro juicio, tal resultado no es posible puesto que no hay elementos que permitan tal conclusión, especialmente si se aprecia que el período de sospecha ni siquiera se fija en atención a la acreditación de una fecha de cesación de pagos. Lo que podrá presumirse en razón de la tipología del acto, tal como expresan los artículos 287 y 290 LRLAEP, es únicamente el perjuicio a los acreedores.

${ }^{53}$ Como indica LEÓN (2004), p. 1304, aunque para el Derecho español, la facilitación del ejercicio de las acciones rescisorias especiales ha implicado la prescindencia del elemento subjetivo o la intención fraudulenta, al tiempo que tampoco se exige la apreciación de insolvencia del deudor en el momento de realizar el acto objeto de impugnación, aun a costa de la inevitable inseguridad en el tráfico. Pero deberá comprenderse que tales prescindencias se dan en la Ley concursal española en la construcción de cualquier clase de acto o contrato cuya rescisión se pretende, y no se limita, como en el ordenamiento jurídico chileno, a los casos en los que se trate de actos jurídicos gratuitos o que resultan asimilados a ellos para estos fines.
} 
se encontraban previo a la celebración del acto o contrato en cuestión provocará la pérdida de la asignación patrimonial o el resurgimiento de la deuda, circunstancias que el tercero podrá perfectamente ponderar como posibles en atención al carácter gratuito del acto.

Respecto a los pagos anómalos, por su parte, creemos que el resultado se produce de idéntica manera. En el caso de los pagos anticipados, el tercero bien podrá ponderar los efectos que esta situación puede producir en los derechos de los demás acreedores, si efectúa la proyección en su posición de cobro, lo que sólo incentiva a la recepción anticipada de la prestación si el tercero puede representarse que sus resultados tendrán un carácter inocuo (lo que, hemos indicado, es muy complejo), o que vislumbre que, en el caso de apertura de un procedimiento concursal, puede verse obligado a restituir aquello en lo que ha consistido el pago para sujetarse a las reglas distributivas del concurso. En el caso de las daciones en pago, el tercero deberá someter a juicio dos elementos para asegurar la conservación de sus efectos, como son la coincidencia del valor del bien recibido en pago con el monto de la obligación que resulta extinguida (o, incluso, un monto mayor), o que el bien que efectivamente ha recibido no se configura como un elemento esencial para el desarrollo de las actividades del deudor. Si bien el primer aspecto puede ser ponderable con anticipación (por ejemplo, sometiendo el bien a una valoración técnica que anticipe prueba ante un eventual ejercicio de la acción), el segundo elemento puede resultar más complejo, y debería implicar una actuación anticipatoria más intensa por parte del tercero con relación al conocimiento de la forma en la que dicho bien se integra al proceso productivo del deudor.

Finalmente, respecto al otorgamiento de garantías reales para el aseguramiento de obligaciones preexistentes, el riesgo se presenta de manera cierta. No siendo habitual que, una vez concedido el crédito, el deudor esté dispuesto al otorgamiento de una garantía para reforzar el cumplimiento, su perfeccionamiento parece producirse especialmente en atención al riesgo de insolvencia que el tercero observa respecto al deudor. Siendo de este modo, deberá asumir cabalmente el riesgo de revocación, puesto que estamos frente a un caso en que la propia tipología del acto se justifica en el perjuicio que esta clase de negocios representa para la masa pasiva.

\subsection{El perjuicio a la masa pasiva en los casos de revocación subjetiva}

En el ámbito de la revocación subjetiva, que, en rigor, sólo se presenta respecto a los actos o contratos celebrados por la empresa deudora con anterioridad al inicio del procedimiento (artículo 288 LRLAEP), la alusión al perjuicio de la masa pasiva se advierte como una de las alternativas justificadoras de la reintegración patrimonial. 
Para aclarar el punto, debemos iniciar esta referencia indicando que la posibilidad de revocación subjetiva se presenta, en nuestro sistema, como regla general respecto a la empresa deudora, sin dar a lugar una tipología precisa de los actos y contratos que pueden ser estimados como perjudiciales por esta vía ${ }^{54}$. Conforme a lo anterior, ya no es posible justificar la acción en razón de la clase de acto impugnado y en su celebración durante un período de sospecha, como en la revocación objetiva, sino que será necesario concretar un elemento subjetivo, basado en el conocimiento del mal estado de los negocios por parte del tercero (scientia decoctionis) ${ }^{55}$, y en una noción de perjuicio, que, en ambos supuestos, requieren ser acreditados por medio de los legitimados activos. Así, en lo que se refiere al perjuicio, no se construye su acreditación por medio de una presunción legal, puesto que el artículo 288 LRLAEP no confiere un catálogo de actos en los cuales tal elemento podría estar situado de manera subyacente ${ }^{56}$.

Respecto al perjuicio en la revocación subjetiva, éste se desdobla en aquél que implica una disminución patrimonial del activo de la empresa deudora (dado el mayor valor comercial de los bienes que aquél que recibió como consecuencia del acto o contrato cuestionado) y aquél que provoca una alteración de la posición de igualdad que deben tener los acreedores al interior del concurso. En este punto, nos centraremos únicamente en la segunda de dichas posibilidades, lo que da lugar a tres observaciones:

\footnotetext{
54 Puga (2014), p. 465.

${ }_{55} \mathrm{Al}$ respecto, no creemos que la noción de mal estado de los negocios pueda entenderse como una situación de incumplimientos íntegros y oportunos, Contador y Palacios (2015), p. 296, aunque este puede ser uno de los medios para evidenciarlo. A nuestro juicio, el concepto está dado por una noción algo más laxa que la insolvencia (a la que no se puede identificar plenamente en razón del uso disímil de los términos en el artículo 155 C.C.), pero que igualmente nos permite entender que estamos ante una situación patrimonial crítica que quizás podría presentar indicios de recuperabilidad a futuro, por ser de menor intensidad. Es por ello que, en el citado artículo 155 C.C., el mal estado de los negocios del marido no siempre dará lugar a la separación judicial de bienes, puesto que el marido podrá oponerse en la medida que rinda cauciones que aseguren suficientemente a la mujer, cuestión que no es posible en caso que la causal esté dada lisa y Ilanamente por la insolvencia. Nuestra jurisprudencia se ha aproximado escasamente al concepto, pero ha indicado que "el mal estado de los negocios -que no es sinónimo de pobreza- debe buscarse en la relatividad actual del pasivo con el activo liquidable y la mayor o menor facilidad de realización" (sentencia de la Corte Suprema, de fecha 11 de diciembre de 1937, disponible en la Gaceta de los Tribunales, 1937, $2^{\circ}$ semestre, № 99, p. 432). En todo caso, obsérvese el alejamiento a la idea de cesación de pagos que se establece en la norma, a diferencia de lo previsto en el artículos 77 y 78 del Libro IV del Código de Comercio, y que la acerca con mayor fuerza a la nomenclatura dada para la acción pauliana civil del artículo 2468 C.C., y que, en consecuencia, merezca el apelativo de mala fe.

${ }^{56}$ Solución diversa a la que se plantea en el artículo 119 de la Ley concursal argentina, en que el elemento de perjuicio está sujeto a una presunción simplemente legal, PESARESI (2003), p. 35.
} 
En primer término, si bien la alusión al perjuicio, en tanto elemento constitutivo de la revocación subjetiva, sólo se efectúa expresamente en relación a la afectación a la masa activa, nos parece que tal calificación es asimismo aplicable a la alteración a la igualdad de los acreedores concursales como resultado del acto o contrato impugnado. Lo anterior puesto que la historia legislativa nos da cuenta de que la referencia a la vulneración a la par condicio creditorum fue agregada en la discusión ante la Comisión de Constitución, Legislación y Justicia de la Cámara de Diputados ${ }^{57}$, como una alternativa al tratamiento que el mensaje de la ley había dado originalmente a este tipo de acción revocatoria ${ }^{58}$. De ahí que la norma en comento utilice la conjunción "o", de modo que tal alteración no constituye un requisito que deba presentarse de manera conjunta, sino alternativa, al perjuicio a la masa activa para el éxito de este tipo de revocación subjetiva ${ }^{59}$.

Asimismo, la calificación de dicha alteración como una forma de perjuicio reposa, por una parte, en la idéntica construcción de la relación de causalidad entre el acto o contrato impugnado y, en este caso, la alteración a la posición de igualdad que deben tener los acreedores en el concurso, como una estructura que se presenta uniforme en toda la estructura revocatoria; y, por otra parte, en la justificación general de la revocación concursal aludida en el capítulo introductorio de este trabajo, en el sentido de que no es posible concebir la posibilidad de dejar sin efectos los actos o contratos celebrados por el deudor por esta vía, sin que pueda apreciarse alguna suerte de detrimento al interés satisfactorio colectivo de los acreedores ${ }^{60}$.

\footnotetext{
57 Así se expresó la entonces Superintendenta de Quiebras, Sra. Josefina Montenegro, ante la Comisión de Constitución, Legislación y Justicia de la Cámara de Diputados (Historia de la Ley № 20.720, p. 2213). Expresión que además, conforme señala SANDOVAL (2014), p. 269 permite incardinar las acciones revocatorias en uno de los principios que informan los procedimientos colectivos de insolvencia. En este punto, el Derecho comparado, a partir de la reacción normativa en los ordenamientos anglosajones, se refiere a las operaciones preferentes (preference), que constituyen una de las categorías de actos sujetos a revisión junto a las operaciones infravaloradas (transactions at an undervalue). Ver CNUDMI (2004), p. 172.

${ }^{58}$ Historia de la Ley $N^{\circ} 20.720$, pp. 113 y 114, en referencia al entonces artículo 287.2 del proyecto de ley.

${ }^{59}$ Como posibilidad alternativa al perjuicio tipificado en la norma como el efecto del acto que se aleja de las condiciones de mercado. Véase Sandoval (2014), p. 270; Puga (2014), p. 465.

${ }^{60}$ Nuestra doctrina no ha efectuado la reconducción propuesta de modo expreso. Así, PugA (2014), p. 465; CONTADOR y PalACIOS (2015) p. 297, siguiendo la definición de perjuicio prevista en el artículo 288.2 LRLAEP, sólo analizan la afectación de la masa activa desde esta óptica. Únicamente SANDOVAL (2014), p. 270, parece ofrecer una posición similar a la que expresamos: el citado autor interpreta la alteración de la posición de igualdad que deben tener los acreedores en el concurso desde la idea de la obtención, en razón del acto o contrato, "de una ventaja apreciable frente a los demás acreedores".
} 
En consideración a lo anterior, en segundo lugar cabe observar que el perjuicio a la masa pasiva aparece aquí constreñido a la afectación de las reglas de prelación de créditos, y no configurado en los mismos términos generales que en materia de revocación objetiva, como todo perjuicio a los acreedores. Conforme a esta redacción, podría entenderse que la operatividad de la revocación subjetiva estará dada en este caso, por ejemplo, para las daciones en pago o los derechos reales de garantía constituidos para asegurar obligaciones preexistentes más allá del período de sospecha que marca generalmente el artículo 287 LRLAEP (un año), ampliándolo por dos años, pero ahora requiriendo también de la concurrencia del elemento subjetivo dado por el conocimiento del tercero contratante del mal estado de los negocios de la empresa deudora.

Pero ello nos lleva a preguntarnos si es posible el ejercicio de una acción revocatoria subjetiva respecto a actos que, sin alterar las reglas de prelación de créditos, hubiesen implicado un detrimento de las posibilidades de pago de los acreedores. A nuestro juicio, pueden ofrecerse dos soluciones. La primera, que ello sólo sería posible en el caso que dicha disminución se produjese como consecuencia refleja del detrimento patrimonial que implica el perjuicio a la masa activa (dado el menor valor asignado al bien en el acto o contrato que se pretende revocar), lo que dejaría fuera de la órbita de acción los actos que han recaído sobre bienes esenciales para el funcionamiento de la empresa o respeto de la unidad económica cuando su apreciación ha sido ajustada a los valores de mercado. La segunda, que el perjuicio a la masa pasiva, en términos amplios, debe tener un carácter expansivo puesto que éste se articula de mejor modo con la debida coincidencia entre la finalidad del concurso y el objeto perseguido mediante el ejercicio de las acciones revocatorias concursales, como es aquél que pretende una maximización de las posibilidades de cobro de los acreedores. Como se verá, el primer argumento supone una estricta interpretación gramatical de la norma, acorde con la preferencia aparentemente dada en el artículo 19.1 CC a dicho elemento; al tiempo que la segunda se enmarcaría en una interpretación teleológica, fundamentada en expedientes sistemáticos y lógicos (artículos 19.2 y 22 CC), buscando la coincidencia con la orientación satisfactoria del concurso y que comprende a la acción revocatoria como un mecanismo arbitrado para la tutela del crédito ${ }^{61}$ y como un modo general de evitar el perjuicio a los acreedores ${ }^{62}$.

Ventaja, que a nuestro juicio, debe ser entendida como la contrapartida del detrimento ocasionado al resto de la masa pasiva en sus posibilidades de cobro.

${ }^{61}$ En este sentido, nuestra doctrina generalmente estudia la acción pauliana en el contexto de los derechos auxiliares de los acreedores. Por todos, AвELIuk (2014), pp. 879-881.

${ }^{62}$ Puga (2014), pp. 439-440, aunque en el sentido de que "[E]n la base de toda revocación está el perjuicio que el acto irroga a los acreedores". 
Por último, y en tercer lugar, cabe consultarnos sobre el contenido de la noción de igualdad de trato de los acreedores. A nuestro parecer, ella debe ser leída desde la perspectiva del juicio al que debe someterse al acto o contrato en el sentido de si, como consecuencia de éste, se produce una reordenación de las posibilidades de cobro de un acreedor en particular, alterando el diseño de justicia distributiva que subyace en las reglas de prelación de créditos. En este punto, cabe considerar que, previo a la situación de crisis patrimonial, las reglas de prelación no deben entrar en juego, puesto que en una fase fisiológica del estado de los negocios del deudor, aún existe libertad para el deudor de efectuar el pago de las obligaciones al tiempo de su vencimiento, como, asimismo, generar alteraciones en la oportunidad de pago de los créditos ${ }^{63}$. Por ello, la referencia a la igualdad de trato no debe ser considerada como el mero juego de las reglas de prelación que podría terminar por revocar toda clase de pagos o constituciones de garantía que hubiesen modificado los términos de la masa pasiva del concurso, sino sólo aquéllos que se han presentado en consideración al inicio de una fase patológica en el patrimonio del deudor ${ }^{64}$.

El problema de esta construcción, sin embargo, tiene una naturaleza temporal ${ }^{65}$. Como expresa el artículo 288.2 LRLAEP, la lesión se da en razón a la alteración de "la posición de igualdad que deben tener los acreedores en el concurso". Pero, el acto o contrato cuya revocación se pretende ha sido precisamente celebrado con anterioridad al mismo. García-Cruces indica al respecto que "la justificación de la ineficacia de aquellos actos anteriores del deudor no podría ampararse -en sentido estricto- en su significado de lesión a la igualdad de los acreedores ${ }^{\prime \prime 6}$, puesto que la composición de la masa pasiva y la aplicación del concepto de igualdad se desprenden precisamente al interior del concurso, como expresa la norma antes señalada. Así, como expone el mismo autor, una lectura literal del precepto conduciría a una incorrecta asignación del riesgo de revocación, puesto que el tercero no se encontraría en condiciones de encontrar la información suficiente para anticipar esta forma de daño ${ }^{67}$.

\footnotetext{
63 García-Cruces (2012), p. 123.

${ }^{64}$ En este sentido GARRIDO (1999), p. 120, señala que “...si se considera el momento en el que el deudor es insolvente, se aprecia cómo ha de aplicarse el principio de proporcionalidad: cuando el deudor es insolvente, el pago al acreedor que primero lo solicite se convierte en un supuesto de preferencia, una causa de preferencia que no tiene origen negocial ni legal".

65 Ambrosini (2000), pp. 4 y 5.

${ }^{66}$ García-Cruces (2012), p. 125.

${ }^{67}$ En razón de lo anterior, la jurisprudencia española ha matizado el punto indicado que "ha existido un auténtico sacrificio patrimonial, que no se da en todos los actos de disposición patrimonial, por ejemplo, cuando el negocio es oneroso y la prestación realizada por el deudor tiene su justificación
} 
Estimamos que la solución concedida por el ordenamiento jurídico nacional para resolver el punto se refleja normativamente en la construcción del elemento subjetivo que confiere la denominación a esta clase de acciones. Así, el conocimiento por parte del tercero del mal estado de los negocios de la empresa deudora será indiciario de que ya estamos temporalmente situados en el contexto de un escenario de crisis patrimonial (esto es, en la fase patológica antes indicada), aun antes de la apertura del concurso. De tal suerte, el acto o contrato impugnado por afectación a la masa pasiva permitirá observar si éste ha tenido o no por objeto una alteración injustificada de la composición de dicha masa. Por medio de ello, se logra una ampliación de la colectividad a la que se hace parte en el concurso, conforme a la lógica de justicia distributiva que le fundamenta ${ }^{68}$. La solución, en todo caso, es diversa a la que se plantea, por ejemplo, en el ordenamiento español, en que la construcción de las acciones de reintegración patrimonial no se configuran en torno a un elemento subjetivo ${ }^{69}$, y que éste sólo es considerado para los fines de la eventual subordinación legal del crédito del tercero de mala fe (artículo 92.6 LC) ${ }^{70}$.

Desde el punto de vista de la distribución del riesgo de revocación, la norma terminará por asignarlo al tercero en la medida en que la alteración de las reglas de prelación se enmarque en el conocimiento que éste posee del mal estado de los negocios del deudor. Este requisito cobrará una importancia crucial para determinar no sólo la posibilidad de revocación, sino que también permitirá, como veremos, la sanción que implica la subordinación del crédito que resulte en su favor en razón de los pagos que haya realizado en razón del contrato que resulte finalmente rescindido. Se logra así, a partir de lo anterior, una solución similar a la anticipada en el ordenamiento español, aunque por medio de un expediente diverso.

A modo de ejemplificar todo lo anterior, si la empresa deudora y el tercero han creado una garantía real para asegurar el cumplimiento de obligaciones que se constituyen en el marco del mismo negocio, en principio no debería existir la posibilidad de revocación del acto si su foco no se ha centrado en el conocimiento del mal estado de los negocios del deudor por parte del tercero. $\mathrm{Si}$, por el contrario, esta operación se ha celebrado precisamente en razón del

en una contraprestación de valor patrimonial equivalente. Y, además, es preciso que dicho sacrificio carezca de justificación SANJUÁN (2012), p. 135.

${ }^{68}$ Ambrosini (2000), p. 5.

${ }^{69}$ Y, como señala García-Cruces (2012), p. 125, pasa por la objetivización del fundamento al que responde la reintegración concursal, dada por el perjuicio a la masa activa, como se desprende del artículo 71.1 LC.

70 FerRé (2005), pp. 301-317. 
estado patológico del patrimonio del deudor, aun en la esfera de un mecanismo de rescate, la revocación constituye un riesgo que debe ser observado por parte de los contratantes, especialmente el tercero en cuyo favor se ha constituido, puesto que puede pesar sobre sí el riesgo de revocación ${ }^{71}$. En este punto, creemos que la regla se construye como un incentivo para que las operaciones de rescate planteadas de la manera antes indicada tengan lugar en el contexto de protección concedida en el marco de un procedimiento concursal de reorganización, que, respecto a este tipo de negocios, resultará precisamente tutelado en razón de las salvaguardias que plantea la normativa aplicable. Al efecto, y a fin de dar protección a los acreedores preconcursales, el artículo 74 LRLAEP establece límites en razón del monto del nuevo financiamiento (que no superen el $20 \%$ del pasivo señalado en la certificación contable referida en el artículo 55 LRLAEP) o de quien concede el crédito (que no podrá tratarse de personas relacionadas), a menos que, en ambos casos, se logre la autorización de acreedores que representen al menos el cincuenta por ciento del pasivo; al tiempo que se consagra un arco temporal de resguardo, dada por el período de protección financiera concursal (artículo 2.31 LRLAEP), considerando especialmente la intervención a la que se encuentra sometida en el deudor a contar de la publicación en el Boletín Concursal de la resolución de reorganización (artículo 57.2 LRLAEP). De este modo, el escudo que protege a la operación se otorgará siempre que los fondos sean utilizados para el financiamiento de las operaciones de la empresa deudora, circunstancia que deberá acreditar el veedor (artículos 74.IV y 74.II LRLAEP), como un modo de encauzar esta clase de financiamiento de rescate a la finalidad propia del procedimiento concursal de reorganización, como es el de mantener vivas empresas aparentemente viables sobre la base de la continuidad de sus operaciones. Sólo en este caso, se logrará una tutela privilegiada del crédito en el marco de un eventual procedimiento de liquidación refleja, justificada en la falta de suscripción del acuerdo de reorganización (artículo 74.IV LRLAEP), y una inmunidad revocatoria en los términos del artículo 76.II LRLAEP ${ }^{72}$.

En este sentido, la formulación de mecánicas de rescate de la empresa deudora fuera de un procedimiento concursal de reorganización, no gozarán del correspondiente escudo protector al cual se refieren las normas antes citadas,

\footnotetext{
${ }^{71}$ Como señala Bermejo (2002), p. 116, "[L]as externalidades de esta utilización estratégica de las garantías reales pueden, sin embargo, internalizarse mediante reglas diseñadas con tal propósito (en nuestro ejemplo, mediante un sistema adecuado de retroacción y acciones revocatorias concursales, o incluso a través de reglas específicas que solventen los problemas resultantes de la infracapitalización), y sin necesidad de sacrificar los beneficios que las garantías reales reportan al mercado del crédito".

72 En sentido favorable a esta inmunidad se pronuncia la Guía Legislativa. CNUDMI (2004), p. 175.
} 
precisamente por los riesgos que éstos pueden producir en la posibilidad de cumplimiento del resto de los acreedores. Y, en este sentido deben leerse los resguardos tomados por el legislador para su operatividad en el marco de los artículos 74 y 76 LRLAEP antes indicados, justificativos de la inmunidad concursal ${ }^{73}$.

Finalmente, si observamos la idea del riesgo de revocación nos parece nuevamente que el sistema ofrece una solución correcta. Lo anterior, quizás no únicamente en razón del perjuicio a la masa pasiva, sino por la necesidad que el legitimado activo de la acción compruebe el elemento dado por el efectivo conocimiento del mal estado de los negocios. Si logra acreditarse este extremo, podrá asumirse que el tercero ha actuado de mala fe (en razón de la reconducción conceptual ya prevista en el artículo 2468 CC), lesionando además los intereses de la masa pasiva, y se entenderá celebrado precisamente en consideración a la eventualidad de la apertura del concurso, en especial, en razón del hecho que ya se han presentado evidencias de una situación patrimonial crítica por parte de la empresa deudora. Así, en caso que el tercero opte igualmente por la celebración de esta clase de actos o contratos, resultará que lo hará tomando sobre sí el riesgo que deba proceder a la restitución del bien recibido o a la cancelación de las garantías otorgadas en el período de sospecha, al tiempo que, para ciertos casos, también se encontraba disponible la articulación del negocio en el marco de un procedimiento concursal de reorganización que le hubiese conferido una inmunidad revocatoria, que parece haber rechazado.

\subsection{Reacción normativa ante el acto perjudicial a la masa pasiva}

Constatados todos los elementos de las correspondientes acciones, el tribunal deberá proceder a la dictación de la sentencia definitiva que declare la revocación solicitada (artículo 292 LRLAEP). Se trata ésta de la principal solución dada por nuestro ordenamiento, pero que, nuevamente, se comportará de manera diversa dependiendo del acto o contrato revocado.

Si estamos frente a un acto o contrato que ha servido de título para la enajenación de un bien, el resultado principal será su restitución material o jurídica al patrimonio del deudor, comportándose propiamente como una acción de reintegración patrimonial ${ }^{74}$. En este sentido, alejándose de la construcción de

\footnotetext{
${ }^{73}$ Con ello, creemos dar pasos para resolver el problema planteado por PugA (2014), pp. 465 y 466, relativo a la posibilidad de entender que la alteración de la posición de igualdad no puede afectar al que deviene acreedor merced de ese contrato (garantía contextual).

${ }^{74}$ En similar sentido, acudiendo, eso sí, a la lógica de la nulidad (y no de la inoponibilidad), el ordenamiento francés ordena una eficacia erga omnes de la pérdida de valor del acto, ordenando, por una parte, la reconstitución del activo mediante la restitución del bien en cuestión y, por la otra, se
} 
las acciones revocatorias como acciones de inoponibilidad en el Libro IV del Código de Comercio, los efectos de la sentencia serán propiamente rescisorios ${ }^{75}$, de manera que las partes deberán retrotraerse al estado en el que se encontraban previo a su celebración o ejecución ${ }^{76}$.

De ahí que tenga sentido que, conforme señala el artículo 292.II LRLAEP, la parte condenada deberá restituir efectivamente la cosa a la masa, y tendrá derecho a la restitución de lo que hubiere pagado con ocasión del acto o contrato

sujetarán al régimen de las prestaciones mutuas para que así se produzca también una recomposición del pasivo, Pérochon (2014), p. 675.

${ }^{75}$ En nuestro ordenamiento, la idea de la rescisión no puede ser identificada con la noción de nulidad relativa, sino que da cuenta de una respuesta genérica por parte del ordenamiento jurídico ante un acto que, por diversos motivos, debe ser dejado sin efectos, En general, ALCALDE (2010).La nulidad relativa se basa en la existencia de vicios propios en la constitución del acto relacionado con el estado o calidad de las partes, que, como es apreciable, no logran identificarse en los actos que pueden ser revocados en la operatividad de las acciones revocatorias. Esta confusión ha llevado, a nuestro juicio, a una errónea interpretación del artículo 2468 C.C., como, a su vez, a que el legislador de 1982 (Ley $\left.N^{\circ} 18.175\right)$ alterara la naturaleza jurídica de esta clase de acciones con la denominación de acciones de inoponibilidad, aunque la doctrina igualmente le asignaba igualmente un efecto restitutorio. Incluso, ante la reforma a nuestro sistema concursal, SANDOVAL (2014), p. 261), mantiene su posición respecto a la naturaleza jurídica de esta clase de acciones, fundado en la relatividad de quienes pueden pedir su declaración y en el carácter relativo de la revocación, sólo en la medida para evitar que dicha persona sufra perjuicio. En el sistema italiano, por ejemplo, la extensión de la naturaleza de la acción revocatoria ordinaria a la revocación concursal ha producido que, en la constatación del efecto de su ejercicio se siga identificando como una ineficacia relativa, sólo respecto a la masa de acreedores, de manera que el bien no deja de ser de propiedad del tercero, sino que sólo es recuperado por el concurso a efectos de su liquidación y posterior distribución, haciendo excepción a la regla de responsabilidad patrimonial universal que sólo coloca en el campo de acción de los acreedores los bienes pertenecientes a su deudor, Nigro y Vattermoli (2009), p. 182, lo que se reitera en nuestro entorno por Puga (2014), p. 434. Lo anterior no es, a nuestro juicio, aplicable a las acciones revocatorias concursales tratadas en el Capítulo VI de la LRLAEP, puesto que la restitución a la que se refiere el artículo 292 LRLAEP se refiere a un reintegro jurídico del bien al patrimonio del deudor, y a la destrucción completa del acto o contrato que ha servido de causa al mismo, dando lugar, en consecuencia, a la restitución de los pagos recibidos en razón del mismo. En similar sentido, PUGA (2014), p. 472, aunque califique la acción como de mera declaración de revocabilidad.

${ }^{76}$ De ahí que pueda someterse a juicio crítico los resultados que fueron consolidándose por medio de la doctrina y jurisprudencia con relación a la posibilidad de reintegración patrimonial por medio del ejercicio de una acción de inoponibilidad. En el Derecho italiano, por ejemplo, la reconducción de la naturaleza jurídica de esta clase de acciones a aquélla prevista en el artículo 2901 del Codice Civile (revocatoria ordinaria o pauliana civil), y, por tanto, a una ineficacia relativa del acto (para nosotros, inoponibilidad) ha llevado a la comprensión que "el objeto de la demanda de revocación no es el bien en sí, sino la reintegración de la garantía patrimonial genérica de los acreedores mediante la sujeción a la ejecución y, por tanto, a la liquidación de un bien, que, respecto a los intereses de los acreedores, viene en consideración sólo por su valor" (Paluchowskı (2013), p. 767, traducción del autor), negando, por tanto, toda posibilidad restitutoria del bien. 
revocado ${ }^{77}$, debiendo verificar ese monto en el procedimiento concursal respectivo $^{78}$. Obsérvese, sin embargo, que esta última posibilidad no se dará con relación a todos los casos de revocación de títulos de enajenación, sino sólo en la medida que hubiese mediado una contraprestación ya pagada.

Por de pronto, no tendrá lugar en el caso de las donaciones, conceptualizadas como contratos puramente unilaterales, ni en las remisiones de deuda, en que no hay contraprestación. Si el acto revocado se refiere directamente a un pago (sea éste un pago anticipado, una dación en pago u otro), debe tenerse presente que no necesariamente se está impugnando además el acto o contrato constitutivo de la obligación. De este modo, no es posible pensar que estamos propiamente en la hipótesis que señala el artículo 292.II LRLAEP, en el sentido de permitir la devolución de lo que éste hubiese pagado con ocasión del acto o contrato revocado. Así, el tercero podrá verificar el crédito en el concurso conforme a las reglas generales, pero no se verá sometido a la regla especial de subordinación que dispone la norma.

Finalmente, si el contrato revocado se refiere a la constitución de garantías reales para asegurar obligaciones preexistentes, no tendrá lugar propiamente una restitución del bien, a menos que se trate de una garantía para cuyo perfeccionamiento hubiese mediado una entrega (como en el caso de la prenda civil o mercantil $)^{79}$. En este caso, lo que corresponde es la revocación de la garantía (practicando las inscripciones y cancelaciones que fueren pertinentes, si se trata de garantías registrales, como la hipoteca o la prenda sin desplazamiento, conforme dispone el artículo 292.I LRLAEP), de manera que el acreedor sea caracterizado conforme a la graduación que le hubiese correspondido sin ella, probablemente como valista. Tampoco tendrá lugar la regla de posposición legal del crédito porque la revocación no se refiere al acto o contrato que dio origen a la obligación, sino a la garantía real constituida, por lo que no nos encontramos jurídicamente ante una contraprestación.

En otro sentido, creemos que en los casos en los que la justificación de la revocación se hubiese dado en razón de un perjuicio a la masa pasiva, no sería procedente el ejercicio del derecho del tercero para mantener la cosa en su

\footnotetext{
${ }_{77}$ Restituciones que, a nuestro juicio, deben efectuarse conforme a las reglas de las prestaciones mutuas de los artículos 904 y siguientes C.C., por tratarse de las reglas generales aplicables también a las acciones de carácter rescisorio (artículo 1687 C.C.).

${ }^{78}$ Como señalan Nigro y VatTermol (2009), p. 183, se trata de un crédito posterior a la apertura del concurso, $y$, en este sentido, no debería entenderse afecto al mismo, pero por expresa voluntad de la ley se asimilan a los créditos anteriores para efectos de su recuperación.

${ }^{79}$ Pero ello no para la reintegración del patrimonio del deudor, del cual no han salido en razón de tratarse de títulos de mera tenencia.
} 
patrimonio previo pago de la diferencia de valor entre el acto o contrato revocado y el valor que considere prevaleciente en el mercado bajo similares condiciones a las existentes a la época de dicho acto. Lo anterior porque la norma, veremos más adelante, hace referencia a un supuesto de perjuicio a la masa activa, esto es, al patrimonio del deudor, dado precisamente por los efectos patrimoniales de este tipo de actos. En suma, aun cuando estemos frente a una revocación objetiva de donaciones, de pagos anticipados o de daciones en pagos, o frente a una revocación subjetiva basada en la alteración al principio de igualdad que deben tener los acreedores en el concurso, la reacción normativa estará únicamente dada por la revocación, conforme a las reglas antes indicadas. Lo anterior se justifica porque el perjuicio resultante de la proyección de la que venimos hablando no siempre se resarciría si el tercero restituyese el valor del bien. La alteración de las posibilidades de pago se ha dado, como hemos dicho, no sólo en razón de su salida del patrimonio del deudor, sino por la alteración de las reglas de prelación de créditos o por la imposibilidad de integrarlo a una eventual reorganización o liquidación integral de los bienes.

\section{El perjuicio a la masa activa}

\subsection{Elaboración conceptual}

Se refiere este punto a un detrimento patrimonial experimentado directamente por el deudor, esto es, a la reducción del patrimonio del que dispone para el cumplimiento de sus obligaciones, sea en el ámbito de una liquidación o ejecución patrimonial, sea en el contexto de la reorganización de la empresa o de la renegociación de sus deudas. Lo anterior, como resultado de un acto o contrato celebrado en el período de sospecha fijado por el legislador, que, dependiente del caso, se asociará o no con un elemento subjetivo.

Aun cuando la norma no lo indique expresamente, como ocurre en el Derecho comparado (artículo 71 LC) ${ }^{80}$, creemos que esta noción de perjuicio, dada su posterior elaboración en los artículos pertinentes, en nada se refiere a la producción de un estado de insolvencia ${ }^{81}$. Esta última construcción sólo es propia del ejercicio de la acción pauliana civil, aunque pueda ser importada a efectos de la rescisión de los actos a título oneroso celebrado por la persona

80 García-Cruces (2012), p. 129.

${ }^{81}$ O, como indica LEÓN (2004), p. 1307, se prescinde de una construcción que ofrezca la necesidad de acreditar un nexo causal del acto con el resultado de la insolvencia en la que se encuentra el deudor al tiempo del ejercicio de la acción revocatoria. El nexo causal, si es que puede así establecerse, se referirá a las consecuencias perjudiciales de las que tratamos, que, variarán en cada caso, conforme a los diversos tipos de perjuicio que contienen las normas aplicables de la LRLAEP. 
deudora con anterioridad al inicio de un procedimiento concursal de renegociación o de liquidación de bienes (artículo 290.IV LRLAEP). Para estas acciones civiles, la doctrina y jurisprudencia nacional ha señalado que el perjuicio en estos casos está dado por la creación o agravamiento de la insolvencia del deudor, en que sí se debe verificar una relación causal entre el acto y el estado patrimonial en crisis ${ }^{82}$.

Pero, en los modelos de acciones propiamente revocatorias consagradas en el Capítulo VI de la LRLAEP, el punto a considerar se refiere exclusivamente a un término matemático que, en razón de los efectos del acto o contrato que se pretende impugnar, implique una merma en el patrimonio del deudor. En este punto, y a diferencia del perjuicio a la masa pasiva antes mencionado en el contexto de la revocación objetiva, el ordenamiento no arbitra presunción alguna, de manera que siempre corresponderá a los legitimados activos de las acciones revocatorias dar cuenta de su existencia. Nuevamente, al tiempo que el artículo 288 LRLAEP no contiene un catálogo de actos, sino que se dispone a modo de regla general, será necesaria la comprobación del elemento subjetivo (scientia decoctionis) y objetivo (perjuicio), a efectos que el acto celebrado en el período de sospecha previsto en la norma pueda ser efectivamente revocado. A su vez, en el caso de las reformas estatutarias, el perjuicio patrimonial se referirá precisamente a su disminución, lo que veremos, puede ocasionar ciertos desajustes.

En estos casos, el perjuicio supone un ejercicio puramente numérico, que está dado por una reducción del patrimonio disponible del deudor, sin que sea necesaria la acreditación que se ha producido un deterioro de las posibilidades de pago para los acreedores. Aquí encontramos que la lesión se efectúa en el patrimonio mismo, que normalmente redundará en una menor posibilidad de satisfacción de los acreedores en el contexto del concurso $^{83}$, pero este último extremo parece encontrarse implícito en la figura, de manera que no será necesaria su comprobación ${ }^{84}$. De este modo, no hay una proyección de los resultados del acto, puesto que ellos se habrán producido inmediatamente en el patrimonio del deudor como consecuencia de su ejecución o celebración.

\footnotetext{
82 Abeliuk (2014), p. 911; Sandoval (2014), p. 259. Así se ha pronunciado también nuestra jurisprudencia, por ejemplo, en sentencia de la Corte Suprema, Rol 3217-2015, de 7 de mayo de 2015. En similar sentido, PugA (2014), p. 450, aunque con el matiz que dado que se requiere del conocimiento del mal estado de los negocios, sólo puede haber creado la insolvencia, sino sólo agravado.

${ }^{83}$ Contador y Vergara (2015), p. 290.

${ }^{84} \mathrm{Si}$ bien podría indicarse que el perjuicio a los acreedores se encuentra sujeto a una presunción iuris et de iure en esta clase de acciones, nos parece que ello no se refleja en el texto normativo. Creemos, al contrario, que dicho perjuicio se encuentra subsumido en el necesario resultado de la disminución patrimonial.
} 
Sin embargo, en razón de esta desarticulación normativa, bien podría ocurrir que, aun cuando la operación se ha ajustado a los valores del mercado, se produzca igualmente una lesión a la maximización de las posibilidades de cobro de los acreedores (como en los casos en los que el objeto de la prestación ha estado dado por un bien que se integraba funcional y esencialmente a las unidades económicas que componen el patrimonio), caso en el cual, como hemos indicado, sólo una interpretación teleológica podría implicar la revocación de dicho acto, pero no en consideración al perjuicio del que tratamos en esta sección, sino por afectación a la masa pasiva ${ }^{85}$.

\subsection{El perjuicio a la masa activa en la revocación subjetiva}

Para estos efectos, el artículo 288.2 LRLAEP, junto con exigir que el acto o contrato haya tenido lugar durante un período de sospecha de dos años anteriores al inicio del concurso y la acreditación del elemento subjetivo (dado por el conocimiento del contratante del mal estado de los negocios de la empresa deudora), la revocación está particularmente sujeta a que se cause un perjuicio a la masa. En este punto, sin embargo, la regla no hace referencia expresa de si se está refiriendo a la masa activa o pasiva del concurso, pero creemos que ello se resuelve fácilmente en favor de la primera si se atiende al concepto de perjuicio que continúa desarrollando la norma.

Así, el mencionado artículo 288.2 entiende la existencia de dicho perjuicio en atención a que las estipulaciones contenidas en el acto o contrato se alejen de las condiciones y precios que normalmente prevalezcan en el mercado para operaciones similares a la época del acto o contrato ${ }^{86}$. Por ello, la regla concreta un perjuicio a la masa activa que se traduce en la disminución del patrimonio del deudor, en razón del desequilibrio que se produce en atención a los efectos del acto o contrato que pretende ser revocado ${ }^{87}$, sin admitir un criterio

\footnotetext{
${ }^{85}$ En este sentido parecen pronunciarse CONTADOR y PALACIOS (2015), p. 298, al indicar que "[A] unque el citado artículo 288 no señala, que si la Empresa Deudora o el tercero contratante acreditan que el acto ejecutado el contrato celebrado no produjeron perjuicio a la masa de acreedores, no debe acogerse una acción de revocabilidad objetiva, nada obsta para ejercer esta defensa, por cuanto el segundo de los requisitos que establece la norma es, precisamente, la existencia de perjuicios para la masa o la alteración de la posición de igualdad que deben tener los acreedores en el concurso".

${ }^{86}$ En general, en el Derecho extranjero se habla de la posibilidad de revocación de las operaciones infravaloradas (CNUDMI (2004), p. 171), pero nos parece que la regulación chilena sobre este punto es más completa y permite incluir operaciones sobrevaloradas, cuando ese mayor valor también perjudique la situación patrimonial del deudor.

${ }^{87}$ Norma de similar tenor encontramos en el artículo 67.1 LF (modificado por el Decreto Ley 35/2005) que consagra la posibilidad de revocación del acto oneroso cuando existe desproporción en las prestaciones en perjuicio del patrimonio del deudor. La diferencia, sin embargo, es que para estos
} 
expansivo, como el que se ha apreciado en otros ordenamientos (especialmente, el español), en el que se trata de insertar la idea de otras formas de perjuicio, particularmente a la masa pasiva, precisamente por la reducción de las cuotas que pudiesen recibir los acreedores en razón de una liquidación concursal (por ejemplo, mediante pagos que no se sujeten al principio de paridad de trato) ${ }^{88}$.

Esta referencia puede dar lugar a varias observaciones. En primer término, que la redacción que nos indica que el perjuicio se entenderá existir en los términos previstos en el artículo 288.2 LRLAEP, no debería ser tomado como un mero ejemplo o como un modo en que se presume la existencia del perjuicio a la masa activa. Ello puesto que lo que ha pretendido el legislador es efectuar una descripción del concepto a efectos de evitar una discusión jurisprudencial sobre el punto, tal como se había presentado en la jurisprudencia del Libro IV del Código de Comercio, lo que podía llevar a incertidumbres y una menor seguridad en el tráfico jurídico (favor concursus) ${ }^{89}$. Ello queda en mayor evidencia si se atiende especialmente al hecho que el artículo 292.I LRLAEP ordena al tribunal a señalar, en el texto de la sentencia que acoge la revocación del acto, la diferencia de valor entre el acto o contrato revocado y el valor que considere prevaleciente en el mercado bajo condiciones similares a las existentes a la fecha de dicho acto, y en la opción que se otorga al tercero para conservar el bien previo pago de dicha diferencia, debidamente reajustada e incluyendo los intereses fijados por el juez desde la fecha del acto o contrato hasta la fecha de pago efectivo (artículo 292.II LRLAEP). Ello implicaría que no puede apreciarse este tipo de perjuicio en los casos en los que no se compruebe el nivel de desequilibrio que la ley establece, puesto que no habría una adecuación con el concepto señalado, por ejemplo, si el bien dado en permuta en nada aporta al desarrollo de los negocios de la empresa deudora o si se trata de bienes que, aun cuando tengan un idéntico valor venal, son de difícil realización ${ }^{90}$.

efectos la norma ofrece un parámetro para medir su magnitud, dado por una diferencia de un cuarto entre aquello a lo que se ha obligado el deudor en relación con aquello que debe recibir. La norma previa a la modificación fijaba, en todo caso, un criterio similar al que ahora se establece en nuestro artículo 288.2 LRLAEP, en el sentido que el desequilibrio no fijaba medidas precisas, sino que debían ser estimadas por el tribunal, sobre el particular, MAFFEI (2013), p. 410.

${ }^{88}$ LEÓN (2004), p. 1307.

${ }^{89}$ Contador y Palacios (2015), p. 297.

${ }^{90}$ En el Derecho comparado, una enunciación genérica del perjuicio a la masa pasiva da cuenta de resultados más bien expansivos. Por ejemplo, "que el acto o la omisión perjudicial afecta al patrimonio del concursado, como género, porque directa o indirectamente afecta los intereses de ese patrimonio valorados en el concurso atendiendo a la proyección que deviene del momento en que se realizan un a un escenario distinto como es aquel en el que no se hubieran realizado", SANJUÁN (2012), p. 143. 
En segundo término, la norma hace referencia a que la diferencia de valores debe observarse en relación con el momento en que se celebró el acto o contrato cuya revocación se pretende, y es en este sentido que el criterio comparativo está dado por las condiciones y precios que normalmente prevalezcan en el mercado para operaciones similares a la época del acto o contrato. La comparación, en suma, no se extiende al valor que eventualmente hubiese tenido la cosa al tiempo del ejercicio de la acción revocatoria, puesto que estas variaciones no son necesariamente apreciables por las partes, e, incluso pueden resultar totalmente ajenas a su voluntad, por lo que no parecía conveniente su inclusión sin "grave merma de una básica exigencia de seguridad jurídica"91. Por su parte, el método comparativo admite una extensión que debe ser modulada en razón de las condiciones precisas en las que se encontraba la empresa deudora al tiempo de la celebración del acto o contrato, considerando especialmente que era de conocimiento, al menos del tercero contratante, del mal estado de sus negocios. De tal suerte, la referencia a las "operaciones similares" que efectúa la norma no debe asimilarse sin más a un promedio de las condiciones de mercado, sino que deberán tener en cuenta los rasgos particulares del negocio llevado a cabo por las partes ${ }^{92}$.

Por último, la norma no parece sujetarse únicamente al valor que se asigna a los bienes o al dinero, según el caso, que son objeto del intercambio. En este sentido, la referencia también está dada a toda otra suerte de estipulaciones contractuales que se alejen de las condiciones normales de mercado. Se trata aquí de una norma abierta que puede ser objeto de una interpretación expansiva del concepto por parte del tribunal, aun cuando creemos que este aspecto también debe observarse desde la lógica del perjuicio a la masa activa, y siguiendo el razonamiento que identifica este supuesto con el valor asignado a los objetos de las prestaciones asumidas por las partes, dando como resultado la ponderación de aquellas estipulaciones que establecen un sacrificio patrimonial que excede las condiciones del mercado. De este modo, por ejemplo, podrán ser objeto de revocación las operaciones de crédito de dinero en las que la tasa de interés supera las que imperan en el mercado, incluso para quienes se encuentran en una situación de mal estado de los negocios, o cuando se haya establecido una renta que no se ajusta a las condiciones comparables en el mercado del arrendamiento.

Recogiendo todos dichos elementos, si atendemos nuevamente al criterio de correcta distribución del riesgo de revocación, estaremos frente a una

91 García-Cruces (2012), p. 126.

92 Puga (2014), p. 466. 
construcción que no sólo debe tener en cuenta esta particular noción de perjuicio, sino que se refleja especialmente en el establecimiento del conocimiento del mal estado de los negocios del deudor por parte del tercero contratante como requisito de ejercicio de la acción. En este sentido, acreditado que sea este elemento cognitivo, resultará que el tercero bien podrá ponderar si los términos en que se está llevando a cabo la operación podrían implicar un detrimento en el patrimonio del deudor, especialmente si se atiende a un juicio preventivo que ajuste los términos del acto a condiciones similares a las que prevalecen en el mercado.

\subsection{El perjuicio a la masa activa en las reformas a pactos y estatutos sociales}

El artículo 289 LRLAEP contiene dos formas de revocar ciertos actos societarios que no encontraban tratamiento expreso en el Libro IV del Código de Comercio, y que, en este caso, sólo son aplicables a la empresa deudora puesto que sólo en ella puede darse una fórmula asociativa en la que existan propiamente pactos o estatutos sociales ${ }^{93}$. Sólo trataremos del supuesto incluido en el primer inciso de la norma, puesto que nos parece que el contemplado en el segundo (relativo a las reformas de estatutos y pactos sociales de filiales y coligadas que, a la vez, son garantes personales de la empresa deudora) no responde propiamente a la lógica de las acciones revocatorias, como tampoco se producen identidad de efectos (en este caso, la inoponibilidad de la reforma para aquellos acreedores que hubiesen contratado con anterioridad a la reforma estatutaria $)^{94}$.

El tipo contenido en el artículo 289.I LRLAEP está dado por la reforma a los pactos o estatutos sociales de la propia empresa deudora dentro de los seis meses anteriores al inicio del procedimiento concursal, en la medida que ellas importen una disminución de su patrimonio. La norma, aunque no lo señala directamente, parece referirse a las disminuciones de capital o a los efectos que pueden conseguirse en razón de una división o de una fusión societaria, y se dirigen, no en contra del deudor, sino de sus socios o accionistas, quienes son los que han llevado a cabo la reforma estatutaria ${ }^{95}$. El tema de la división social

\footnotetext{
93 Sandoval (2014), p. 270.

${ }^{94}$ Sin embargo, si quisiese establecerse la noción de perjuicio que inspira la norma, esta probablemente se encontraría en un deterioro de la garantía, cuestión que, por otra parte, ya encuentra esbozos de un tratamiento normativo, por ejemplo, en los artículos 1496.2 y 2349 C.C. En este sentido, ConTADOR y PalACIOS (2015), p. 299, al indicar que su justificación está dada en razón del resguardo del patrimonio de los garantes.

95 Puga (2014), p. 467, aunque agregue que, al menos en el caso de los accionistas, el hecho que la reforma estatutaria deba aprobarse en el seno de la Junta de Accionistas, en tanto órgano social, implica
} 
había pretendido ser abordado por las normas previstas en el artículo 2468 CC y el Libro IV del Código de Comercio ${ }^{96}$, por medio de una jurisprudencia que había concluido que los actos de división social son propios del deudor (aunque se trate de decisiones tomadas por los socios, especialmente en el caso de sociedades de personas) y que, la calificación del acto como gratuito u oneroso resultaría improcedente puesto que en ningún caso podría requerirse el conocimiento del mal estado de los negocios por parte de los adquirentes, ya que éstos serían las sociedades que se crean como consecuencia de la división societaria ${ }^{97}$.

A nuestro juicio, la artificialidad de dicho razonamiento que, a la larga, parecía sustentarse en razones de justicia material, soportan la base de esta posibilidad de revocación especial. Debe observarse, además, que la norma incorporada pretende suplir una de las carencias dadas por nuestra legislación societaria, en el sentido que no establece salvaguardias para que los recursos propios disponibles puedan efectivamente cubrir su ejercicio ni constituir un soporte para las obligaciones contraídas, pudiendo dar lugar a supuestos de infracapitalización real o nominal ${ }^{98}$. Tampoco encontramos en nuestro sistema jurídico, medidas que ofrezcan seguridad a los acreedores frente a supuestos de reestructuración societaria, como posibilidades de oposición, o reglas de responsabilidad solidaria por parte de las sociedades resultantes, por ejemplo, en casos de división ${ }^{99}$.

Cabe precisar que serán tres los requisitos previstos por la norma: (i) un elemento temporal, que fija un período sospechoso de seis meses; (ii) un elemento tipológico, que hace referencia a las reformas de pactos y estatutos sociales; y (iii) un elemento de perjuicio, dado por la disminución del patrimonio del deudor, destacando que, en caso alguno, envuelven un elemento subjetivo.

Respecto al elemento del perjuicio, cabe hacer una observación previa. La construcción del precepto parece haber tomado como modelo lo dispuesto en el artículo 74.3 de la Ley $N^{\circ} 1.116$, de insolvencia empresarial colombiana, que se refiere a "las reformas estatutarias acordadas de manera voluntaria por los socios, solemnizadas e inscritas en el registro mercantil dentro de los seis meses

que se trata de un acto de la sociedad. Y, en consecuencia, que podría haber sido revocable conforme a las reglas generales, sin necesidad de una disposición expresa en este sentido.

96 Contador y Palacios (2015), p. 299.

${ }^{97}$ En este particular, puede consultarse la sentencia de la Corte Suprema, Rol 3816-2011, de 16 de abril de 2012.

98 LEÓN (2012), p. 183.

${ }^{99}$ Reglas consagradas, por ejemplo, en la legislación española (artículos 44.1 y 80 de la Ley 3/2009, de 3 de abril, sobre modificaciones estructurales de las sociedades mercantiles). 
anteriores al inicio del proceso de reorganización, o del proceso de liquidación judicial, cuando ellas disminuyan el patrimonio del deudor, en perjuicio de los acreedores, o modifiquen el régimen de responsabilidad de los asociados".

Nótese sobre el particular que esta última regla sitúa el perjuicio del acto en cuestión por medio de dos antecedentes que difieren de la redacción dada por el ordenamiento jurídico chileno. El enunciado del artículo 74 de la ley colombiana hace referencia de modo genérico al perjuicio que se haya provocado a cualquiera de los acreedores, al tiempo que luego, ya en el marco específico de las reformas estatutarias, la referencia a la disminución del patrimonio del deudor aparece sólo como un medio de afectación a los intereses de los acreedores. En este sentido, el perjuicio que servirá de base para apreciar la revocabilidad de la reforma estatutaria estará dado en Colombia por la efectiva afectación de las posibilidades de cobro de los acreedores, no bastando, al efecto, la mera acreditación de la disminución patrimonial. En nuestro ordenamiento, en cambio, esta construcción se efectúa con una única referencia al perjuicio de la masa activa, $y$, aunque pudiese resultar consecuencial el deterioro a las posibilidades de cobro por parte de los acreedores, dicho elemento no resulta en un requisito para la procedencia de la acción, de manera que el perjuicio que establece la norma proviene de un mero cálculo matemático.

Al respecto, sólo aclarar que la norma aquí parece confundir los términos "capital" y "patrimonio", dada la repetición de los conceptos contemplados en el ordenamiento colombiano, puesto que el último no tiene referencia expresa en los estatutos sociales ${ }^{100}$. De este modo, siempre deberá observarse la consecuencia económica del acto en cuestión, no bastando la mera referencia a la reforma llevada a cabo ${ }^{101}$.

La acción revocatoria que, en estos términos parece dirigirse a la sociedad o a sus socios o accionistas, implicará que estos deberán ponderar los efectos de su decisión en el patrimonio social. La ausencia de un elemento subjetivo puede dificultar en este caso el juicio relativo al riesgo de revocación, puesto que nada importa si quienes han tomado parte en la decisión o se han visto

${ }^{100}$ En este sentido se pronunció el profesor Rafael Gómez Balmaceda en la Comisión de Constitución, Legislación y Justicia de la Cámara de Diputados, en el marco del segundo trámite constitucional de la ley (Historia de la Ley № 20.720, p. 1962), lo que es confirmado por SANDOval (2014), pp. 270 y 271, señalando que "[E]s evidente que los conceptos de capital social y de patrimonio social son diversos, toda vez que el primero es de naturaleza contable y se mantiene fijo, en cuando no se reformen los estatutos para aumentarlo o disminuirlo. Por el contrario, el concepto de patrimonio social comprende tanto los bienes que la entidad adquiere con el capital social, formando los diferentes activos, como así también los diversos pasivos que se generan y es esencialmente evolutivo, porque su incremento o disminución depende de las vicisitudes del negocio".

101 SANDOVAl (2014), p. 271. 
afectados por la misma, han tenido conocimiento de los efectos patrimoniales de la reforma estatutaria ni del estado de los negocios de la empresa deudora al tiempo de la adopción del acuerdo. En este sentido, la norma parece asumir el conocimiento de los socios de tales extremos ${ }^{102}$, al igual que de parte de los terceros que pueden haber tenido participación en el acto, como en un supuesto de fusión, lo que advierte la exigencia implícita de un nivel de diligencia informativa mayor por parte de todos los intervinientes ${ }^{103}$.

\subsection{Reacción normativa ante el acto perjudicial a la masa activa}

En este punto, la primera reacción normativa se presenta de manera idéntica que la referida para los actos perjudiciales a la masa pasiva. Así, la primera consecuencia estará dada por la retroacción de las partes al estado previo a la celebración del acto o contrato, debiendo, por una parte, restituir material o jurídicamente el bien a la masa, y, por la otra, proceder a la verificación del crédito en el concurso respectivo. Así, por ejemplo, tendrá cabida en casos de compraventas o permutas, a las que se hace referencia en el artículo 288.2 LRLAEP, y en todos aquellos casos en los que ha existido alguna suerte de contraprestación que ha sido satisfecha por el tercero ${ }^{104}$.

Respecto a la verificación, la norma agrega una regla de posposición legal hasta el pago íntegro de todos los créditos valistas, pero creemos que ello sólo puede tener lugar en el ámbito de la revocación subjetiva, donde propiamente existe un crédito de reintegración. De este modo, el riego de revocación se extenderá al riesgo de subordinación legal del crédito que resulte de la operación, cuestión que se fundamentará precisamente en el elemento subjetivo/cognitivo previsto para la revocación subjetiva, dado por su exposición aun a pesar del

\footnotetext{
102 En este sentido, en el Derecho colombiano, RodríGuez (2007), p. 530.

${ }^{103}$ En caso que la reestructuración societaria se hubiese llevado a efectos durante el período de negociación de un acuerdo de reorganización, el paraguas protector estará dado únicamente en el caso en que, conforme al artículo 57.2.c) LRLAEP se tratare de un caso en que fuese necesaria la transferencia de acciones de la empresa deudora, caso en el cual el veedor deberá verificar que con ello no se alteren los derechos de los acreedores (a menos que se trate de una sociedad anónima abierta que haga oferta pública de sus acciones). Cualquier otra medida que requiera de la modificación de los pactos o estatutos sociales se encuentra prohibida en este período, y, por tanto, será sancionada con la nulidad absoluta del acto.

${ }^{104}$ En este sentido, entendemos que la posibilidad que el tercero verifique el crédito en el concurso, aun subordinado, sólo podrá tener lugar en caso que efectivamente hubiese hecho restitución material del bien. Como informa el artículo 292.V LRLAEP, en caso de no hacerlo, el apremio debe efectuarse mediante las reglas del cumplimiento forzado, por lo que podría producirse una distancia temporal entre el momento en que la sentencia quede firme y ejecutoriada y el momento de entrega, no siendo lógico que, sin mediar ésta, el tercero pueda verificar el crédito, tener eventualmente derecho a voto, e, incluso, participar en la distribución del activo.
} 
conocimiento del mal estado de los negocios de la empresa deudora y al resultado lesivo a la masa activa del concurso. Aquí, la reacción parece más intensa, y, a nuestro juicio, se basa en la utilización de las reglas de prelación de crédito como un mecanismo sancionatorio a la conducta del deudor desplegada, en este caso, con anterioridad al inicio del procedimiento concursal ${ }^{105}$.

Como hemos indicado, esta reacción se presenta coincidente con los resultados que se ofrecen en el ordenamiento comparado, en los casos en los que la naturaleza de la acción revocatoria sea propiamente rescisoria, y, en consecuencia, de reintegración patrimonial. Al efecto, el ordenamiento español procede a la subordinación del crédito derivado de la rescisión contractual con apreciación de la mala fe (artículo 92.6 LC), haciendo girar el concepto desde la idea que "habría que analizar si el tercero conocía o no podría ignorar que el acto que se estaba llevando a cabo carecía de justificación material y en consecuencia suponía una despatrimonialización en perjuicio de la masa activa"106. No obstante, cabe observar que en este resultado se está localizando a la noción del perjuicio que propone el artículo 71 LC, como base de la apreciación de la mala fe, lo que en nuestro sistema se logra de modo diverso, puesto que éste debe construirse en razón del conocimiento, no de la eventual lesión que produce el acto, sino únicamente del mal estado de los negocios del deudor. Ello resultará de la identidad conceptual que se refleja entre el artículo 288.1 LC con el artículo 2468.1 CC. En este sentido, la legislación concursal chilena ofrece una orientación, en términos que la sanción que impone la subordinación del crédito no se justifica en la acreditación de un animus nocendi (o, al menos, en una culpa con o sin representación del resultado del acto o contrato cuya revocación se pretende), sino que todo el sistema se reemplaza por un elemento más simple, que, a juicio del legislador patrio, resulta suficiente para acreditar la procedencia del requisito, tanto para los fines de la revocación subjetiva del artículo 288 LRLAEP, como de la subordinación automática del crédito dispuesta consecuencialmente en el artículo 292.II LRLAEP.

Lo anterior es coincidente con el enfoque se ha dado tradicionalmente a este elemento subjetivo en la legislación nacional, que puede rastrearse hasta la configuración de la acción pauliana en nuestro Código Civil. De hecho, resulta concluyente que, en esta materia, el codificador ya había desatendido la dicción de los antecedentes que se ofrecían en el Code Civil francés (artículo 1167), en que la revocación gira en torno a la noción del fraude a los acreedores ${ }^{107}$,

${ }^{105}$ El carácter sancionatorio que, creemos, fundamenta la norma permite eludir las críticas esbozadas por Puga (2014), p. 493, que califica esta decisión legislativa como una "burla" o un "verdadero abuso".

106 ÁvILA DE LA TORRE (2012), p. 807.

107 Para una extensa referencia sobre el particular, en general, SAUtONIE-LAGUiOnE, (2008). 
para conceder un elemento subjetivo de menor dificultad probatoria, como es el referido al conocimiento de la situación patrimonial del deudor ${ }^{108}$. De tal suerte, en la construcción de los instrumentos revocatorios a nivel nacional, las figuras no se han sujetado a nociones que se funden en la existencia del citado animus nocendi, de modo tal que la reacción legislativa que tratamos se arbitra en torno a otras justificaciones, no volitivas, sino meramente cognitivas.

Sin embargo, dado que estamos ante casos en que el perjuicio está dado por elementos puramente matemáticos de disminución patrimonial, el ordenamiento nacional arbitra una opción a efectos que el tercero pueda conservar los efectos del acto ${ }^{109}$. Para tales efectos, dentro del plazo de tres días contados desde la notificación del cumplimiento incidental del fallo, podrá acogerse al beneficio de mantener la cosa en su patrimonio previo pago de la diferencia entre el valor fijado en el acto o contrato revocado y el valor que el tribunal considere prevaleciente en el mercado bajo condiciones similares a las existentes a la época de dicho acto. Dichos valores, en todo caso, sólo podrán ser fijados por el tribunal en consideración a la prueba por medio de informe de peritos, que, conforme a la regla del 425 CPC, deberán ser ponderados por el tribunal de acuerdo a las reglas de la sana crítica.

De este modo, el desequilibrio patrimonial que trajo como consecuencia el acto puede ser efectivamente saneado en la medida que el tercero complete la prestación al valor que efectivamente tenían en el mercado los bienes que habían salido de su patrimonio en razón del acto o contrato que ha resultado impugnado, debidamente reajustado e incluyendo los intereses dispuesto por el tribunal, desde la fecha de su celebración, hasta la fecha de su pago efectivo. Esta posibilidad se establece como un derecho potestativo y absoluto para el tercero, de manera que el demandante no podrá oponerse a su ejercicio, sino

\footnotetext{
${ }^{108}$ De hecho, ya había anticipado la doctrina nacional que una versión estricta del fraude pauliano (como animus nocendi) "haría de la acción pauliana un expediente completamente inútil e irrisorio" VARGAS (1949), p. 113. En idéntico sentido, el presupuesto objetivo dispuesto por el ordenamiento italiano también se satisface por el solo conocimiento del estado de insolvencia por parte del tercero (artículo 67 LF), habiéndose consolidado la idea que, así descrito, no puede ser reconducido a la noción de fraude, resultando éste extraño a la lógica de las acciones revocatorias, MAffel (2004), p. 394. Sin embargo, nuestra jurisprudencia ha confundido estos conceptos, de manera que exige, al menos en la órbita de la acción pauliana civil, "que el deudor sea fraudulento, esto es que haya ejecutado el acto o contrato con el ánimo de perjudicar a sus acreedores, representada por el dolo o mala fe, pero con características especiales por cuanto no vicia el consentimiento" sentencia de la Corte Suprema, Rol 30917-2014, de 31 de marzo de 2015.

${ }^{109}$ Lo anterior también se justifica por el hecho que la rescisión se presenta, en este caso, en razón de una causa extrínseca al acto, como es el perjuicio que puede provocar en un hipotético escenario concursal, de manera que comparte la lógica que puede presentarse en el ámbito de la rescisión por lesión enorme, LEÓN (2004), p. 1300. Respecto a la lógica de la rescisión en este ámbito, Alcalde (2010), pp. 66 y 67.
} 
sólo impugnar el monto del diferencial sobre la base de un error de hecho o meramente numérico por parte del tribunal. En suma, dado que la lógica del perjuicio a la masa activa se restringe en nuestro ordenamiento a una mera reducción del patrimonio, esta solución se justifica plenamente como un mecanismo para obtener un reequilibrio que termina por sanear de modo completo el daño experimentado así concebido.

\section{Conclusiones}

a. El perjuicio debe ser comprendido como el elemento central sobre el cual se construye todo el sistema de revocación concursal. Sin embargo, a fin de dar el correcto resguardo a la seguridad del tráfico jurídico, la anticipación del mismo, especialmente por parte de los terceros, debe provenir de la claridad en su construcción, situando correctamente en éstos el riesgo de revocación.

b. A diferencia de las acciones revocatorias dispuestas en el Libro IV del Código de Comercio, en todo el Capítulo VI de la LRLAEP el elemento del perjuicio se presenta de manera expresa. Sin embargo, su construcción se bifurca, según el caso, en perjuicios a la masa pasiva o a la masa activa del concurso, lo que redunda en una diversidad de consecuencias jurídicas, teniendo como punto en común sólo aquello que se refiere a los efectos retroactivos de la revocación.

c. El perjuicio a la masa pasiva parece elaborarse de manera diversa en las acciones de revocación objetiva y subjetiva. En las primeras, se dará por una proyección de los resultados del acto o contrato en las posibilidades de maximización de las posibilidades de cobro de los acreedores en las diversas alternativas de procedimientos concursales, al tiempo que en las segundas se presenta como restrictivo a una lesión a la igualdad de trato de los acreedores al interior del concurso. Sólo por medio de una interpretación teleológica de las normas en torno a las finalidades distributivas del concurso se permitiría una extensión de la revocación subjetiva a aquellos casos en los que el detrimento se refiere, genéricamente, al perjuicio a los acreedores. Conceptualizado de este modo, el riesgo de revocación aparecerá correctamente ubicado sólo en la medida en que los intervinientes del acto perjudicial puedan efectuar la proyección del perjuicio en términos de afectar el valor relativo de los créditos en caso de apertura del concurso.

d. El perjuicio a la masa activa adquiere en nuestro sistema una formulación matemática, tanto en la revocación subjetiva como en aquélla referida a las reformas de pactos y estatutos sociales, dada por la disminución patrimonial. De este modo, no es necesaria una proyección del acto en las pretensiones de cobro de los acreedores, que parecería inmanente al deterioro de la regla de responsabilidad patrimonial universal. En el caso de la revocación subjetiva, el riesgo de revocación parece justificarse en el elemento subjetivo dado por el 
conocimiento del mal estado de los negocios del deudor por parte del tercero, como justificativo de la revisión de las consecuencias del acto a revocar. Por su parte, la ausencia de dicho elemento subjetivo en la revocación de las reformas estatutarias parece asumir que quienes intervienen en el mismo tienen un nivel de información suficiente sobre la situación patrimonial del deudor y de los efectos económicos de sus actos. Construido el perjuicio a la masa activa de tal modo, es posible comprender la alternativa de conservación de los efectos del acto perjudicial por medio del pago del remanente que reequilibre la correspondencia con el valor de mercado del bien dispuesto.

e. La subordinación legal del crédito, como último efecto, sólo podrá darse en la medida en que estemos situados en un negocio de carácter bilateral en que se haya dado cumplimiento a las obligaciones de ambas partes. Como ello sólo es posible en los casos de revocación subjetiva, la solución postergatoria se basará esencialmente en el elemento subjetivo de la revocación, que, mediante la identidad con el artículo 2468 CC, debe calificarse como mala fe. Y, en este sentido, se hace uso de las reglas de prelación de crédito como un mecanismo sancionatorio que pretende el restablecimiento de la justicia distributiva que impera en todo el sistema concursal.

\section{BiBLIOGRAFÍA CITADA}

Abeliuk Manasevich, René (2014): Las obligaciones, $6^{a}$ edición actualizada (Santiago, Legal Publishing Thomson Reuters), tomo II.

Alcalde Silva, Jaime (2010): "La rescisión en el Código Civil chileno", en: AA.VV., Estudios de Derecho Civil V, Jornadas nacionales de Derecho civil (Coord. Departamento de Derecho civil de la Universidad de Concepción) (Santiago, AbeledoPerrot/Legal Publishing), pp. 47-77.

AmBRosinı, Stefano (2000): La revocatoria fallimentare delle garanzie (Milán, Giuffrè).

ÁvILA de LA Torre, Alfredo (2012): "Crédito subordinado", en: AA.VV. Enciclopedia de Derecho concursal (Dirs. Emilio Beltrán y José Antonio García-Cruces; Coords. Ana Belén Campusano y Alfredo Ávila de la Torre (Cizur Menor, Thomson Reuters/Aranzadi), pp. 795-813.

Bermejo Gutiérrez, Nuria (2002): Créditos y quiebra (Madrid, Civitas).

Contador Rosales, Nelson y Palacios Vergara, Cristián (2015): Procedimientos concursales (Santiago, Thomson Reuters/La Ley).

Contreras Strauch, Osvaldo (2010): Insolvencia y quiebra (Santiago, Editorial Jurídica de Chile).

FerRÉ Falcón, Juan (2005): Los créditos subordinados (Cizur Menor, Thomson Civitas). 
García-Cruces, José Antonio (2012): "Acción rescisoria concursal (reintegración concursal", en: AA.VV., Enciclopedia de Derecho concursal (dirs. Emilio Beltrán y José Antonio García-Cruces; coords. Ana Belén Campusano y Alfredo Ávila de la Torre) (Cizur Menor, Thomson Reuters/Aranzadi), pp. 119-149.

GARRIDO, José María (1999): Garantías reales, privilegios y par condicio: un ensayo de análisis funcional (Madrid, Centro de Estudios Registrales).

Goldenberg Serrano, Juan luis (2010): "Consideraciones críticas respecto al denominado principio de la par condicio creditorum", en: Revista Chilena de Derecho (vol. 37, № 1), pp. 73-98.

— (2015): La visión privatista del Derecho concursal (Santiago, Thomson Reuters/La Ley).

Gómez Balmaceda, Rafael y Eyzaguirre Smart, Gonzalo (2011): El Derecho de quiebras (Santiago, Editorial Jurídica de Chile), tomo I.

JACKSON, Thomas H. (1986): The logics and limits of bankruptcy law (Cambridge/ Londres, Harvard University Press).

JaCQuemont, André (2013): Droit des entreprises en difficulté (Paris, LexisNexis Litec).

León Sanz, Francisco José (2004): "De los efectos sobre los actos perjudiciales para la masa activa", en: AA.VV., Comentario de la Ley concursal (dir. Ángel Rojo y Emilio Beltrán) (Madrid, Thomson Civitas), pp. 1297-1335.

—_ (2012): "La rescisión de las operaciones societarias", en: AA.VV., La reintegración de la masa. Congreso de Antequera (dir. Emilio Beltrán y Enrique Sanjuán) (Cizur Menor, Civitas/Thomson Reuters), pp. 182-198.

Maffel AlbertI, Alberto (2013): Commentario breve alla Legge Fallimentare (Padua, Cedam).

MokAL, Riswaal Jameel (2005): Corporate Insolvency Law. Theory and application (Nueva York, Oxford University Press).

Nigro, Alessandro y Vattermol, Daniele (2009): Diritto della crisi delle impesse. Le procedure concorsuali (Boloña, II Mulino).

PaluCHOWSKI, Alida (2013): "Degli efetti del fallimento sugli atti pregiudizievoli ai creditori", en: PAJARDI, Piero, Codice del Fallimento (Milán, Giuffré Editore), pp. 699-863.

PÉROCHON, Françoise (2014): Entreprises en difficulté (París, L.G.D.J.).

PesaresI, Guillermo (2003): "El conocimiento del estado de cesación de pagos en la revocatoria concursal", en: AA.VV. Derecho concursal argentino e iberoamericano (Buenos Aires, Ad-Hoc), pp. 33-45.

Pons AlBentosa, Leopoldo (2012): "Las acciones de reintregración a la masa activa en la Ley 22/2003, de 9 de julio, concursal (aspectos generales, novedades 
introducidas por la Ley 38/2011, de 10 de octubre, casos especiales y experiencias en el Derecho comparado)", en: AA.VV., La reintegración de la masa. Congreso de Antequera (dir. Emilio Beltrán y Enrique Sanjuán) (Cizur Menor, Civitas/Thomson Reuters), pp. 53-85.

Puelma AcCorsı, Álvaro (1971): Curso de Derecho de quiebras (Santiago, Editorial Jurídica de Chile).

Puga Vial, Juan Esteban (2004): Derecho concursal. El juicio de quiebras (Santiago, Editorial Jurídica de Chile), tomo II.

— (2014): Derecho concursal. Del procedimiento concursal de liquidación (Santiago, Editorial Jurídica de Chile).

Rodríguez Espitia, Juan José (2007): Nuevo régimen de insolvencia (Bogotá, Universidad Externado de Colombia).

RogGe, Hendrik y LePTIEN, Friederike (2012): “\$129 InsO”, en: AA.VV., Hamburger Kommentar zum Insolvenzrecht (Colonia, Carl Heymanns Verlag), pp. 1212-1240.

RosApePE, Roberto (2013): "§§ 70-76", en: AA.VV., Diritto fallimentare (Manuale breve) (Milán, Giuffrè Editore).

SANDOVAl López, Ricardo (2014): Reorganización y liquidación de empresas y personas. Derecho Concursal (Santiago, Editorial Jurídica de Chile).

SANJuÁn y Muñoz, Enrique (2012): "El perjuicio para la masa activa", en: AA.VV., La reintegración de la masa. Congreso de Antequera (dir. Emilio Beltrán y Enrique Sanjuán) (Cizur Menor, Civitas/Thomson Reuters), pp. 130-161.

Sautonie-Lagouinie, Laura (2008): La fraude paulienne (París, L.G.D.J.).

Sotomonte MuııcA, David Ricardo (2014): "La acción revocatoria concursal en la legislación colombiana", en: AA.VV., Libro homenaje al profesor Emilio Beltrán (Bogotá, Legis S.A.), pp. 261-277.

TIRADO MARTí, Ignacio (2009): "Reflexiones sobre el concepto de 'interés concursal' (Ideas para la construcción de una teoría sobre la finalidad del concurso de acreedores)", en: Anuario de Derecho Civil (vol. LXII, № 3), pp. 1055-1107. VARGAS VARGAS, Manuel (1949): Tratado de la acción pauliana concursal (Santiago, Ediar Editores Limitada).

\section{NORMAS JURÍDICAS CITADAS}

Código Civil (Chile)

Código de Comercio (Chile)

Ley $\mathrm{N}^{\circ} 18.175$, de 28 de octubre de 1982, de quiebras (Chile) 
Ley $\mathrm{N}^{\circ} 20.720$, de 9 de enero de 2014, que sustituye el régimen concursal vigente por una ley de reorganización y liquidación de empresas y personas, y perfecciona el rol de la superintendencia del ramo (Chile)

Legge Fallimentare contenida en el Regio Decreto 16 marzo 1942, n. 267 (Italia) Insolvenzordnung, de 5 de octubre de 1994 (Alemania)

Ley $N^{\circ}$ 24.522, de 20 de julio de 1995, de concursos y quiebras (Argentina)

Ley 22/2003, de 9 de julio, concursal (España)

Ley $\mathrm{N}^{\circ} 1.116$, de 27 de diciembre de 2006, de insolvencia empresarial (Colombia)

Code de Commerce (Francia)

Code Civil (Francia)

Codice Civile (Italia)

\section{JURISPRUDENCIA CITADA}

Compañía de Acrílicos S.A. contra Industria Textil Selame y Marangoni Ltda. (2004): Corte Suprema 27 de julio 2004 (acción revocatoria concursal) en: Base de datos LegalPublishing, bajo el código CL/JUR/243/2004.

Empresa Constructora Dherco con Mónica Herrera Gayoso (2011) Corte Suprema 27 de septiembre 2011 (acción revocatoria concursal) en: Base de datos LegalPublishing bajo el código CL/JUR/9759/2011.

Jaime Ayala Ríos con KG Inversiones Chile S.A. Sociedad Delta Overseas Investment Limited y Sorensen y Compañía Ltda. (2012): Corte Suprema 16 de abril 2012 (acción pauliana) en: Base de datos LegalPublishing bajo el código CL/JUR/794/2012.

Add Corp. S.A. con Constructora San Pablo S.A. (2012): Corte Suprema 31 de octubre 2012 (acción revocatoria concursal) en: Base de datos de LegalPublishing, bajo el código CL/JUR/2620/2012.

Constructora Endurance S.A. con Vinilit S.A. (2012): Corte Suprema 24 de diciembre 2012 (acción revocatoria concursal) en: Base de datos LegalPublishing, bajo el código CL/JUR/2936/2012.

Pablo Cereceda Bravo con Inverlink Consultores S.A. y otra (2015): Corte Suprema 15 de enero 2015 (acción revocatoria concursal) en: Base de datos LegalPublishing, bajo el código CL/JUR/172/2015.

Pablo Cereceda Bravo con Julio Coloma Henríquez y otro (2015): Corte Suprema 15 de enero 2015 (acción revocatoria concursal) en: Base de datos LegalPublishing bajo el código CL/JUR/199/2015. 
Nabor Urzúa Becerra con Marco Zapata Fuentes y otro (2015): Corte Suprema 19 de marzo 2015 (acción revocatoria concursal) en: Base de datos LegalPublishing, bajo el código CL/JUR/480/2014.

Guillermo Arévalo Alcaman y otra con Ignacio Sobarzo Falcón y otra (2015): Corte Suprema 31 de marzo 2015 (acción pauliana) en: Base de datos LegalPublishing bajo el código CL/JUR/1803/2015.

Importadora y Exportadora Grac S.A. con Inmobiliaria Construcción y Medio Ambiente Green S.A. y otro (2015): Corte Suprema 7 de mayo 2015 (acción revocatoria concursal) en: Base de datos LegalPublishing bajo el código CL/ JUR/2478/2015. 